\title{
Swiss and Alpine geologists between two tectonic revolutions. Part 1: from the discovery of nappes to the hypothesis of continental drift
}

\author{
Jean-Paul Schaer
}

Received: 29 March 2010/Accepted: 28 October 2010/Published online: 14 December 2010

(C) Swiss Geological Society 2010

\begin{abstract}
At the advent of the twentieth century, geologists believed that folded continental mountain chains like the Alps were due to horizontal compression, resulting from contractions of the Earth's crust as it cooled. In 1918, Albert Heim defended this point of view and illustrated it with a geological section across Switzerland. In 1915, however, and in short notes as early as 1912, Alfred Wegener in Die Entstehung der Kontinente und Ozeane (The Origin of Continents and Oceans) proposed that mountains were the result of collisions between light continents drifting and floating on denser formations of the Earth's interior, also present at the bottom of the oceans. Before this (1906), Otto Ampferer had already proposed the association of folds with active movements of material inside the Earth. Wegener used numerous morphological, geological, and gravimetric data to justify his theory. He was innovative in his successful use of paleogeographic and paleoclimatologic reconstitutions. Although very popular, his theory only received reserved approval from the active scientific community. Alpine geologists found it too audacious and too far removed from the field data. In the first critical analysis written in French (1922), Elie Gagnebin welcomed it as a working hypothesis, but was
\end{abstract}

Editorial handling: A.G. Milnes.

\section{J.-P. Schaer $(\bowtie)$}

Institute of Geology and Hydrogeology,

University of Neuchâtel, Rue Emile-Argand 11,

CP 158, 2009 Neuchâtel, Switzerland

e-mail: jean-paul.schaer@unine.ch very reserved regarding the arguments of a geophysicist who, in his opinion, was not sufficiently versed in structural geology. In contrast, Emile Argand integrated Wegener's theory into his conception of the evolution of the Alps already in 1916. At that time, he judged the Alpine orogeny to have been the result of permanent compression and proposed that its whole history had been dominated by what he called embryonic tectonics, a compressional concept which he illustrated so admirably that it had an incomparable and lasting success. However, he himself abandoned it in his major work, La Tectonique de l'Asie (The Tectonics of Asia), in favour of an evolution that first originated in an extension regime, finally leading to the splitting of the continental crust, with local emergence of basic rocks, constituting the bottom of new oceanic floors. It is at the slope of these continental margins, and at their foot, that geosynclines are formed by the large accumulation of sediments transported by submarine slumping. During the following compressive stage, slices of basic ocean floor are transported upwards between overlapping continental masses, forming extensive ophiolitic zones. Although admired for his enormous accomplishment, $L a$ Tectonique de l'Asie remained ignored for its most innovative propositions, which clearly foreshadow plate tectonics. After this work, Argand practically abandoned geology. His last publication (1934), Guide géologique de la Suisse: la zone pennique (Geological Guide to Switzerland: the Pennine Zone), revived his argument of the early evolution of the geosyncline in a context of extension, followed by thrusts involving the ocean floor. Unfortunately, the concept had no greater success than at its first appearance.

Keywords Switzerland - Alps · A. Wegener - E. Argand · Plate tectonics $\cdot$ History of geological ideas 
Résumé Au début du $\mathrm{XX}^{\mathrm{e}}$ siècle, les géologues soutiennent que les chaînes plissées des domaines continentaux sont l'expression de compressions horizontales provoquées par le refroidissement de la planète qui se contracte. Albert Heim défend ce point de vue et l'illustre par un profil à travers la Suisse. Dès 1912, A. Wegener associe les plissements à l'affrontement de continents légers qui dérivent et flottent sur les roches plus denses des profondeurs également présentes au fond des océans. Antérieurement, Ampferer avait déjà proposé que les plissements sont associés à des mouvements de matière actifs à l'intérieur du globe. Pour justifier sa théorie, Wegener utilise des faits morphologiques, géologiques et gravimétriques reconnus. Il innove par d'heureuses propositions de reconstitutions paléogéographiques et paléoclimatologiques. Très populaire, sa théorie reçoit pourtant un accueil réservé de la communauté scientifique active. Les géologues alpins l'estiment trop audacieuse et par trop éloignée des données de terrain. Dans la première analyse critique rédigée en français, E. Gagnebin se montre disposé à retenir l'hypothèse de travail, mais reste fort réservé quant à l'argumentation d'un géophysicien qui, à ses yeux, ne domine pas la géologie structurale. Certaines raisons l'ont conduit au rejet de la théorie de Wegener et plus tard à adopter la même attitude lors de l'arrivée de la tectonique des plaques. Argand intègre rapidement la théorie de Wegener à sa conception de l'évolution de la chaîne alpine. Tout d'abord, il propose que celle-ci est soumise à un régime de serrage permanent qui dicte toute son histoire dominée par le concept de l'embryotectonique qu'il illustre de façon si admirable que celui-ci connaît un incomparable et durable succès. Dans La Tectonique de l'Asie, Argand abandonne l'idée de la permanence de la contraction au profit d'une évolution également marquée par l'extension. Dans ce régime, la croûte continentale est étirée puis fissurée. Dans les cicatrices qui se forment, apparaissent des roches profondes (sima) du plancher de nouveaux océans. C'est là, sur les talus bordiers et à leur pied, que s'accumulent, par glissements sous-marins, les grandes épaisseurs de sédiments dits géosynclinaux. Lors du serrage, les masses basiques, prélevées de ces fonds océaniques, sont entraînées entre les masses continentales chevauchantes pour y former les grandes cicatrices ophiolitiques. Ces propositions, pourtant annonciatrices de la tectonique des plaques, seront largement ignorées. La Tectonique de l'Asie, bien qu'admirée pour le tour de force que représente cette synthèse de géologie structurale couvrant la planète entière, restera méconnue au niveau de ses propositions les plus novatrices. Au-delà de cette oeuvre, Argand abandonne pratiquement la géologie. Le guide de la zone pennique, sa dernière oeuvre, reprendra, sans plus de succès, l'argumentation de l'évolution du géosynclinal par extension, suivie par la mise en place des masses basiques entraînées dans les grands plis penniques.

\section{Introduction}

"The validity of a theory is nothing else but its capability of accounting for all the known facts at the time it is presented. In that respect, the theory of large-scale continental drift is of flourishing validity". (Emile Argand, 1924: La Tectonique de l'Asie, p. 292)

Alpine geologists, and the Swiss in particular, did not play a direct role in the discovery and development of plate tectonics. However, as early as 1918, Emile Argand incorporated Alfred Wegener's theory of continental drift into his vision of how the Alpine chains had developed, and this was later followed up by Rudolf Staub. Both Argand and Staub were Swiss geologists of great influence in their time, and as confirmed "mobilists", it could be expected that the community of Swiss geologists would immediately accept the theory of plate tectonics as soon as it appeared on the scene in the late 1960s. However, the most influential Alpine geologist at that time, Rudolf Trümpy, was slow to follow suit, as can be traced through several his papers in the 1970 and early 1980s, and among many of his colleagues, scepticism reigned. In a recent study, Trümpy himself identified certain reasons that led to this situation (Trümpy 2001), following up several studies, in which he presents the paleogeography prior to the folding, reviews the acceptance of continental drift, and the reactions that accompanied the proposal of plate tectonics within the Swiss geological community and internationally (Trümpy 1960, 1965, 1971, 1973, 1980, 1983, 1985; Trümpy and Oberhausser 1999). In the present study, the history of development of ideas on moving continents is followed more closely, based on the history of geology teaching at the University of Neuchâtel, with such towering figures as Schardt, Argand, and Wegmann, and this sheds light on these partially missed opportunities. This history complements the contributions of Carozzi (1985), Marvin (1985) and Gaudant (1995) devoted to European reactions (British, French, and French Swiss, respectively) to Wegener's theory. The latter studies were expanded upon by Le Grand (1988), Stewart (1990), Oreskes (1988, 1999, 2003), Gohau (1991), Dal Piaz (2001) and Sengör (1990, 1998). Also, the publications by Menard (1986) and Le Pichon (1984, 2000) concerning these questions are valuable additions, because both scientists were very active at the highest level during the plate tectonic revolution, which forms the second part of this saga. ${ }^{2}$ When taking into account the communities that were responsible for plate tectonics, it is necessary to refer mainly to British and American sources. In the present study, which concentrates on the repercussions of the continental mobility on Alpine tectonics, we have given priority to French and German contributions, particularly by Argand and his followers, since they offer interesting 
perspectives that have previously been ignored. Lemoine's work on the how Wegener's theory was received (Lemoine 2004), and Ray's thesis dedicated to the influence of the works of Emile Argand and Pierre Termier (Ray 2004, 2005), represent two recent French contributions that have the same perspective as our analysis.

\section{Ideas on mountain building at the beginning of the twentieth century}

During the second half of the nineteenth century, following proposals by de Beaumont Léonce (1829-1830, 1852), the majority of geologists accept that folds in the Earth's crust result from horizontal compression due to the cooling of the planet, contracting like an apple as it dries up with age. "The dislocations visible in the Earth's crust are produced by movements that result from the decrease in volume of our planet. This phenomenon breaks down into tangential and radial forces, followed by horizontal movements (that is to say, by pressure and folding) and by vertical movements (that is to say, by collapse)" (Suess 1921, Vol. 1, p. 139). They also supposed that, through major subsidence, continental areas could be transformed into oceanic zones, and that these, by folding, could be pushed out of the water again. It was known that neritic sediments of continental zones are not very thick and are of highly variable nature, in contrast to the very thick and monotonous sediments found in mountain chains. de Beaumont Léonce (1828) was the first person to emphasize this contrast by comparing the great thickness of Mesozoic series in the internal Alpine zone to those of the same age in the Paris and London basins (cf. also Sengör 2003b, p. 119-120). Later, the American school called the vast longitudinal zones of subsidence, where these thick sedimentary series originate, "geosynclines". Hall (1859) and Dana (1873) placed the evolution of geosynclines at the edges of continents, whereas Haug (1911, p. 157-171) put them between two continental masses, as did Elie de Beaumont. Later, having been the site of contraction, it was thought that these weak and mobile zones become favoured sites for the creation of mountain chains, pushed up by the folding. Although the "geosyncline" idea was widely used in the Alpine domain, Suess emphasizes his reservations: "I regret having used the expression 'geosyncline' at the beginning of this work; I have since avoided it" (Suess 1921, Vol. 3, p. 1618).

In the folded zones in Europe (e.g. Alps, Scotland, Scandinavia, the Belgian coalfields), regional studies led, at the end of the nineteenth century, to the discovery of the importance of overthrusting (see next section). It was shown that large rock masses had been displaced by many dozens to hundreds of kilometres due to the effects of lateral pressures. They are stacked on top of each other and thrust across the cratonic forelands, often intensely folded and composed of rocks older than those underlying them. The importance of brittle deformation, such as fracturing, faulting and thrusting, was observed to be greater in the upper parts of the Earth's crust. In contrast, the increase in plasticity with depth was observed to lead to continuous deformation and flow (folding, cleavage, etc.) for specific lithologies. The location of mountain chains, the importance of overthrusting, and the nature of the deformation led many researchers to question the validity of the theory of terrestrial contraction. This scepticism was later strengthened by the discovery of radioactivity, which was found to be widely distributed in the Earth's crust, suggesting that the Earth was not, in fact, cooling, and therefore not contracting. Despite the contributions of Joly (1925) and Holmes (1929), the contraction theory survive for many years; in 1939, the eminent geophysicist Beno Gutenberg could still write "In summary, we may state that the thermal contraction of the earth probably explains mountain building in part, but at present the evidence is rather in favour of the assumption that other processes play at least equally important and probably more important role." (Gutenberg 1939, p. 191).

Already in the middle of the nineteenth century, data was being collected which significantly modified ideas on the structure of the Earth's interior, particularly from studies dealing with the distribution of gravity. Scientists at the British Geodetic Service in India were the first to observe that the gravitational effect of the Himalayas is weaker than its apparent mass indicates. In addition, at the edge of the ocean, the topographic depression of the Earth's surface was observed to be accompanied by an increase in gravity. To explain these anomalies, Pratt (1855) considered that large masses of low density rocks, absent from neighbouring plains, must be present underneath the Himalayas. Airy (1855) proposed that light continental rocks, in particular those of mountain chains, lean on and push into a zone of rocks that are denser but very deformable. This was called the isostatic compensation zone and its behaviour was imagined to be comparable to that of a liquid. Gravity measurements made at sea by Hecker (1910) led him to propose that continents and oceans possess fundamentally different compositions, and that these control the altitude of the solid surface of the Earth. Thus, the oceans could not be related to the collapse of continental zones and must have formed by other mechanisms.

At the turn of the century, therefore, ideas on the origin of mountain chains were less and less dominated by the contracting Earth hypothesis, and more and more influenced by the discovery of far-travelled nappes, indicating considerable lateral movement of continents. At the same time, geophysical evidence for the layered structure of the 
Earth and the mechanical properties of the various shells was accunulating. It is against this backcloth that we now look in more detail at ideas on mountain building at the beginning of the twentieth century.

Alpine geologists' interpretation of mountain formation

Towards the end of the nineteenth century, the great overthrust nappes of Glarus (Bertrand 1884) and the Prealps (Schardt 1893) were identified and described. Into the next century, this phenomenon was confirmed in the Helvetic Zone (Lugeon 1902), in the Penninic Zone (Lugeon and Argand 1905), in the Austroalpine Zone (Termier 1903), and also in the Jura Mountains (Buxtorf 1907). Taking into consideration the axial plunges of the nappes, Argand showed that, in the Pennine zone, erosion has exposed rocks that were previously situated more than $20 \mathrm{~km}$ deep in the Earth's crust. Before discussing the pioneering contribution Emile Argand, however, we first look at the ideas of some other authorities on Alpine geology at that time-Heim, Termier and Ampferer.

\section{Albert Heim ${ }^{3}$}

Between 1919 and 1922, Albert Heim (1849-1937) published his impressive, 3-volume work, Geologie der Schweiz (Geology of Switzerland). At the same time, he gave out a paper presenting his views on orogenesis (Heim 1918), which can be considered as a synthesis of contemporary ideas in Swiss geological circles. In the 1918 paper, Heim first presents what he deems to be the Earth's most probably composition and structure (Fig. 1). It's lithosphere reaches $1,000 \mathrm{~km}$ depth and includes three successive envelopes of increasing density. At the surface, horizontal sedimentary rocks (average density 2.6) reach many kilometres in depth. They overlie the "Sal" (later known as "sial"4), an envelope that is mainly made up of aluminium-rich silicates (average density 2.7)—gneisses, schists and other metamorphic rocks, and acid igneous rocks, such as granites. Underlying these rocks are those called at the time "sima" (density 2.8-4.0), a layer mainly made up of magnesium and iron-rich silicates, comprising basalts and "green rocks" (ophiolites, diorites, diabases, gabbros, dunites, and serpentines). It is interesting to note that according to Heim, the transition between the sial and the sima is neither a sharp contact nor is it parallel to the Earth's surface. The vagueness of his sketch (Fig. 1) seems more to illustrate the uncertainties in the data than to suggest mixing between these two zones, or the rise of the sima into the sial. With regard to orogenesis, Heim is still in line with Bertrand and Suess: the cooling of the planet leads to its contraction, ${ }^{6}$ which in turn leads to the

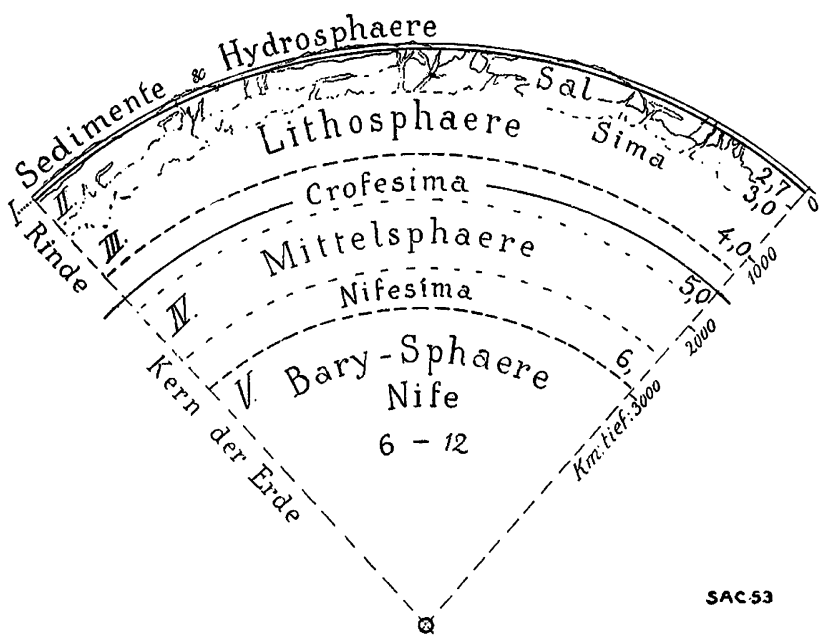

Fig. 1 The successive layers of the Earth, according to Heim (1918). The boundary between the sial (sal upper granitic crust) and the sima (= lower basaltic crust) is drawn as diffuse and irregular, and the Moho is missing (although already discovered). Crofesima chromium and iron-rich sima (density 5), Nifesima nickel and iron-rich sima (density 6), Nife nickel-iron core (density 6-12)

formation of thrust belts. In the Jura mountains, north of the Alps, Heim illustrate the crustal shortening by décollement along the Triassic evaporite series and folding of the overlying 1-2 km thick sedimentary cover (Fig. 2), whereas in the central zone of the Alps, the thrust slab is actually close to $15 \mathrm{~km}$ thick and the folded section in the Alps originally had a thickness of $30-50 \mathrm{~km}$, before the uplift and erosion of the mountain chain. Heim illustrates this using a schematic profile across Switzerland with the volume of sediment removed by erosion. Although unrealistic in detail (the central zone of the Alps is dominantly formed of crystalline rocks rather than the illustrated folded sedimentary assemblage), the overall picture seems to be inspired by the folds that Heim drew, at the beginning of his career, in the carbonate sedimentary series of Säntis (pers. comm. M. Burkhard). With an average topographical relief of the order of 2,000 $\mathrm{m}$, the present-day Alps reach a probable depth of $25 \mathrm{~km}$ below sea level. This is where Heim located the base of the décollement, which locally has a very reduced thickness. Unfortunately, he says nothing about the nature of the rock materials and their evolution in terms of time and depth.

\section{Pierre Termier ${ }^{7}$}

A French view of the deformation of the Earth's crust at this time is provided by the lectures that Pierre Termier (1859-1930) gave in different scientific circles. (For a careful analysis of Termier's positions on this subject and on continental drift, see Ray 2003). Termier distinguished 


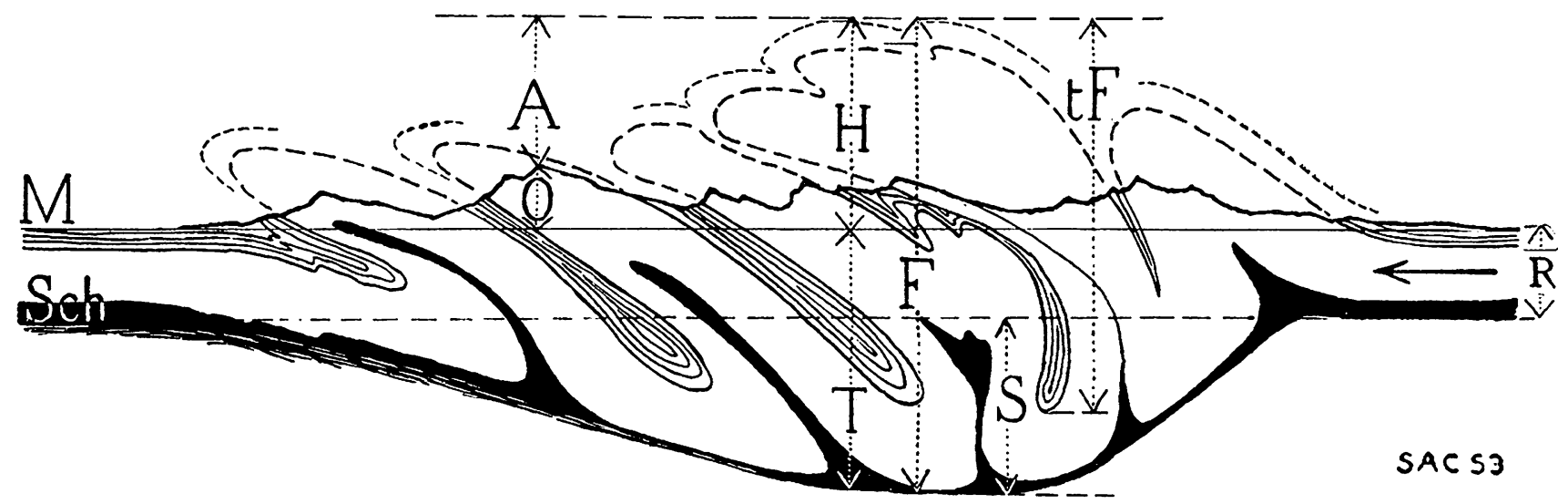

Fig. 2 Schematic structure of a folded mountain chain, from Heim (1918). According to Heim, $M$ is the general level of the Earth's surface, approximately at sea level, both before and after folding. Sch is the base of the part of the crust which will become folded-a shear zone or transition zone which will separate the folded part of the crust from underlying part which will not be affected. $R$ is the thickness of that part of the crust which will be affected by the folding. In the Jura mountains, $R$ is $1,000-2,000 \mathrm{~m}$; in the central zone of the Alps, $R$ is around $15 \mathrm{~km}$ (according to Argand, Heim notes). After the folding

two types of movement: vertical movements able to lower or raise a continent or an ocean floor, and horizontal or tangential displacements that lead to the folding of mountain ranges:

Horizontal or tangential displacements of the surface are the most characteristic features of terrestrial deformation. Each of our mountain chains is a bundle of folds, more or less parallel, a rectilinear bundle over long distances and becoming here and there, sinuous, as if it moulded itself to a uneven border of a resistant obstacle... Some of these recumbent folds have crept on their substratum of folds, by laminating or stretching themselves, ... One can, in certain cases, evaluate the amplitude of the horizontal displacement: it is often more than one hundred kilometres... A strange thing: it is not the same on the lunar surface. ...There is not, on our satellite, any true mountain chain... (Termier 1922, p. 321-323).

For Termier, the interior of the Earth or barysphere, has a rigidity analogous to that of steel. A relatively thin liquid zone, the pyrosphere, separates it from the solid crust or lithosphere. As a true contractionist, he believed that the decrease in size of the barysphere and pyrosphere by a lowering of the temperature would lead to the wrinkling and to the folding of the terrestrial crust:

Periodically then, the lithosphere, which is sufficiently plastic overall, deforms itself in order to find a new position of equilibrium. This will happen, almost always, by the formation of a sort of wave tending to and the establishment of isostatic equilibrium, $T$ is the greatest depth of the shear zone under the original surface, and $H$ is the reconstructed height of the folded rocks above the original surface (now eroded away); hence $T+H$ is the total folded thickness $F . t F=F-R$ is height amplitude of the folding, or the purely tectonic fold height. $A$ is the amount of erosion and $O=H-A$ is the remaining orographic height of the mountain range. $S=T-R$ is the isostatic subsidence

reject, onto the continent, the materials that have accumulated in the neighbouring sea parallel to the shore. (Termier 1922, p. 324).

\section{Otto Ampferer ${ }^{8}$}

As early as 1906, before the Wegener's hypothesis of continental drift, Otto Ampferer (1875-1947) proposed that fragments of the Earth's crust could be caught in zones of lateral displacement due to movements of material located inside the planet, as Fischer (1889) had already proposed: "Vertical movements are always probably the first, the deepest, and the most important, whereas horizontal displacements are only secondary associated events" (Ampferer 1906, p. 253). For Ampferer, these mechanisms, which provide analogies to those of the atmosphere and the hydrosphere, control all the activity of the planet, from folding to grabens, even as far as sedimentary cycles. Up to 1942, Ampferer continued to complete and refine this first hypothesis of global tectonics with numerous notes, in which his vision became gradually closer to that which was ultimately taken by plate tectonics. His prophetic views were almost entirely ignored by Alpine geologists, and for a long time they were not well known by those who developed the plate tectonic theory. For the former, it is possible that Ampferer's colleagues did not welcome his theory with much enthusiasm, because he was so critical of their ideas. Also, his colleagues probably did not have much time to read texts which were not very clear and 
illustrated with purposely roughly drawn figures. Ampferer placed himself squarely in opposition to the geological tradition of his time, especially the Swiss, which tended to associate aesthetic graphics with scientific truth. For him, a sketch was the only way to present the complexity of nature. In his eyes, the nice neat profiles of the Swiss school, whilst trying to be realistic, too often showed suggestive details which had never been observed. According to him, these interpretive and uncertain additions put the mind on wrong paths, from which it is difficult to become detached (Ampferer 1926, p. 142-43). It is certain that after the Second World War and perhaps even before, Ampferer's work did not have the resonance that it deserved because it was published in German by a authority whose criticism nobody appreciated. In addition, although his mapping contribution was greatly appreciated, his theoretical notes never became a vital source of inspiration at the time, even within his own circle.

Other contributions published at the time of Wegener's Die Entstehung der Kontinente und Ozeane (first edition 1915, last edition 1936) show that geologists were more and more conscious that the history of the Earth (the aim of their research) suffered from their poor knowledge of oceans, past and present, even though oceans cover seventenths of the surface of the planet. The influence of Wegener's work is partially related to this situation and to the privileged place he gives to the oceans. Where direct geological observation is impossible, geophysics becomes the leading discipline. Its intensive application to the exploration of the oceans is certainly one of the decisive factors that led to the birth of plate tectonics.

\section{Die Entstehung der Continente und Ozeane (Wegener 1915)}

It is fair to say that it was the meteorologist and geophysicist Alfred Wegener (1880-1930) that laid the groundwork for the main geological revolution of the twentieth century, plate tectonics. By focussing the internal dynamics and geology of the Earth, Wegener was delving into disciplines that appeared to be quite unrelated to his previous work. Author of a well received treaty on the thermodynamics of the atmosphere, his qualities as a researcher were essentially related to the retrieval of meteorological data recorded at high altitude and in extreme conditions, using weather balloons. Even at a young age, he showed a profound interest in the Arctic, where he hoped to participate in scientific expeditions (Schwarzbach 1980). After distinguishing himself by a long flight in a balloon, he became a member of the "Denmark" expedition to Greenland, from 1906 to 1908.
From 1912 to 1913, under the direction of Johan Peter Koch, he returned to Greenland where he undertook a traverse along the 75th parallel with two companions. In 1930, Wegener was made the leader of a large German expedition to Greenland. It was on the inhospitable inland ice that, at 50 years of age, he met a tragic end. Wegener was not exceptional as a geophysicist. It was because of his taste for adventure that he carried out his meteorological research in extreme environments, often confronting conditions just as severe as those sometimes encountered by geologist-explorers on high innaccessible mountain peaks. But through his multidisciplinary interests, he proved himself ahead of his time, compared to his more numerous and specialized colleagues (Lemoine 2000).

Wegener's propositions and the first reactions to them

At the time his first notes on continental drift were published (Wegener 1912a, b), there was only moderate interest in his ideas, because their implications were very often on the fringe of the interests of the geophysical community. However, in geological circles, his proposals were at the centre of pertinent questions of high interest at the time: mountain chain formation, the exchange of fauna between continents, the evolution of oceanic environments, paleo-climatology, the stability of the positions of the poles, etc.

Due to the First World War, the controversy arising from the hypothesis of continental drift, presented in 1915 in Wegener's celebrated work Die Entstehung der Kontinente und Ozeane (The Origin of Continents and Oceans), only raged in German-speaking countries. The natural science communities of those countries acknowledged that the text brought up several interesting problems. However, they were all in agreement that the author relied on insufficient geological knowledge, often used without precaution, and that he did not bring a convincing argument to explain the forces driving the proposed drift of the continents. In the non-professional public, the simplicity of the basic theory and its aspect of surprise tended to make it attractive and apparently accessible. Being so successful, numerous editions were to follow. From the third edition onward, different translations started to appear. As Lemoine (2004) emphasizes, the popularity of the work was partly due to the multidisciplinary approach of its author, but it was also due to the lucidity of the text.

Wegener used the striking fit of the coasts on the opposite sides of the Atlantic as the starting point of his argument, an observation that many researchers had already made. However, this was by no means the work's principal merit. It is more to be found in the ingenious way he argues in support of his idea, and in the knowledge he patiently collects in order to give legitimacy to his 
audacious proposition. Although a meteorologist, his arguments are mostly geological (lithological correlation on either side of the Atlantic), geographical (continental and oceanic altimetry/bathymetry, coastal and oceanic morphology), paleontological (similarities between animal species on different continents), and paleo-climatological (climatic zones based on comparisons of Carboniferous flora). The pages dedicated to the presentation of geophysical arguments (mostly gravimetry, velocity of seismic wave propagation) comprise only one-tenth of those of a geological nature. It is true that in the later chapters of the work, geophysics makes up the main part (interior viscosity of the Earth, ocean floors, sial sphere, folding and disjunction, forces of translation) but always in the context of their geological implications. In addition, the different representations of the light crust floating on the sima that he provides in successive editions were always in conformity with the principles of isostasy (Fig. 3). With regard to gravity and isostasy, his concepts were inspired, as early as 1912, by the data of Hecker (1910) and by the overview of Helmert (1910), and were later confirmed by the first measurements carried out in a submarine by Vening-Meinesz (1927).

In the successive editions of his work, Wegener did not make any fundamental modifications to his approach. He did expand on some his arguments, particularly in the area of paleo-climatology, through the contact he maintained with his father-in-law, Wladimir Köppen. ${ }^{9}$ New was particularly the unexpected grouping of different theoretical proposals with established facts. For instance, the decrease in width of the sediment cover from 600 to $1,200 \mathrm{~km}$ to the width of the Alps (about $150 \mathrm{~km}$ ) he showed to be incompatible with the contraction theory, but explainable with drifting continents. Altogether, the geological facts were used to establish new and coherent proposals, both global and revolutionary, about the evolution of the whole planet. By basing his theories mainly on still very deficient oceanic data (approximate bathymetry, scarce sediment and rock sampling by dragging the ocean floor), Wegener gave due importance to the ocean in proportion to its coverage of the surface of the Earth, already a major step forward. Compared to earlier propositions, the paleogeographical reconstructions that he proposed explained-often in a more satisfactory way than did the conventional geology of that time-the distribution of certain flora and fauna, some paleo-climatological relationships, and numerous features of oceanic and continental morphology. Nevertheless, for many geologists this vision was too far removed from their point of view, too theoretical, and too close to speculation in which field geology was not taken enough into consideration. In addition, a number of renowned geophysicists judged that Wegener did not
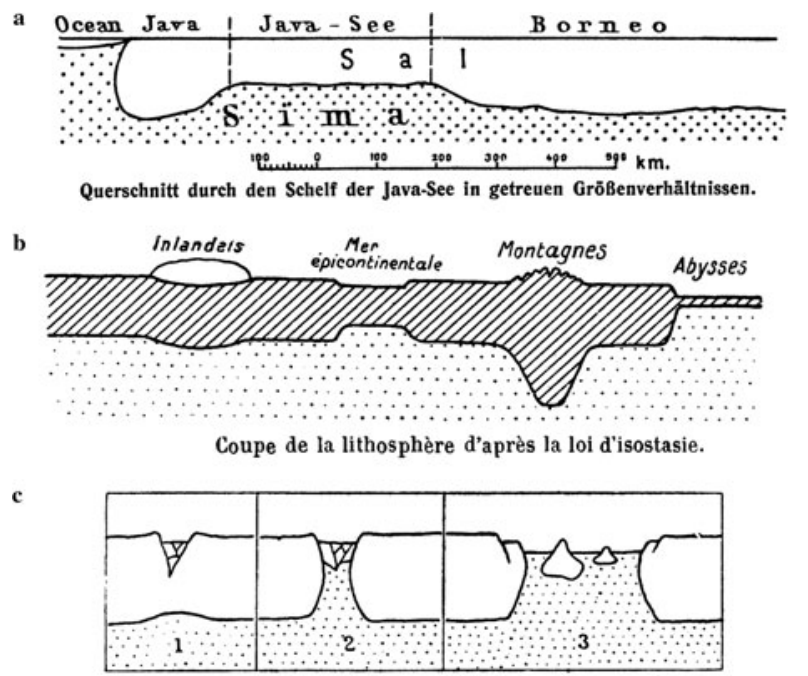

Disjonction (schéma)

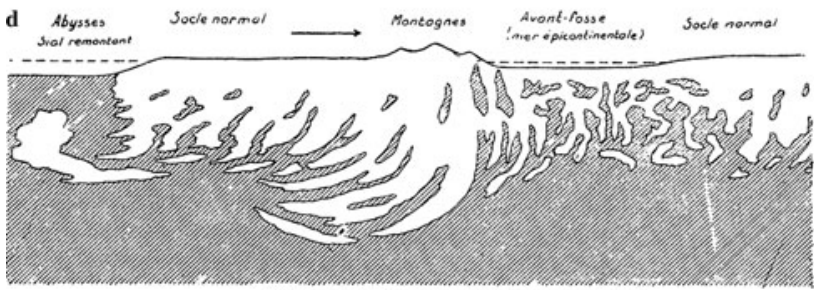

Coupe à travers un socle continental.

e

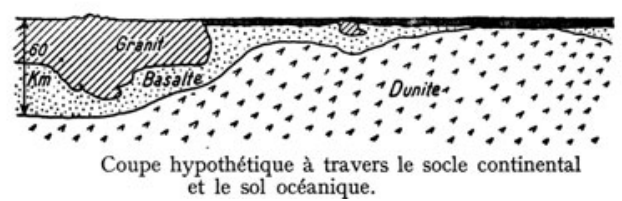

Fig. 3 Wegener's different proposals to illustrate the relationships between the light continental rocks (sial) and the underlying denser rocks ( $\operatorname{sima}$ ) on which the lighter rocks float. a The first illustration of crustal structure and the relationship between "sal" (sial) and sima (Wegener 1912a), on the example of the Java Sea (horizontal and vertical scales equal). b Schematic cross-section of the "lithosphere" (meaning here, light continental rocks $=$ sial) according to the law of isostasy, showing the roots below mountain chains, the flexure caused by glacial loading, the thinning under epicontinental seas and the extreme thinning of the sial under the deep ocean (Wegener 1922). c Schematic view of the disjunctions in the sialic layer (white) caused by continental drift in the extensional mode (Wegener 1922). This illustration could have inspired Argand in his proposals of oceanisation. d A more sophisticated view of the internal structure of the continental basement (sial, white), with pockets of sima as inclusions in the "lithosphere", a possible source of volcanism (Wegener 1922). This cross-section is the mirror image of the right side of Fig. 3b. e Wegener's final proposal (Wegener 1929). Light continental rocks (sial) overlying basaltic rocks (sima), the latter absent in some parts of the ocean (oceanisation?), where then sub-simatic rocks form the ocean floor

completely understand the physical properties of the outer layers of the Earth, which should have supported his theses. They seriously questioned the credibility of his proposals. 
The developing debate

Carozzi (1985) has astutely analysed the reactions of continental Europe to Wegener's work. He shows that up to the beginning of the 1920s, apart from a few authors who adhered to the new ideas, it was the critical attitudes that won over, some of these quite devastating. The theory quickly received an eager welcome in Holland, particularly by those conversant with geological and geomorpological data from Indonesia. This support would continue for a very long time (Sengör 1998, p. 104-114). In the rest of Europe and the world, because of the effects of the First World War, it was not before 1922 that the debate truly developed in the geological literature. There were some admirers but mainly critics, the two sometimes even united in the same person:

One can reject Wegener's theory - and I am one of those who feel great reluctance to adhere to it - but one cannot contest that it is, from certain angles, as seductive as a very beautiful dream, a dream by a great poet. (Termier 1926, p. 130).

In answer to the fundamental question "Are the continents absolutely immobile?", Termier, like all geologists, admitted that the face of the Earth is constantly changing. That being said, he was not willing to accept great mobility of the continents. He recognised certain merits in Wegener's hypothesis, such as the way it satisfactorily explained the analogies of ancient fauna between Africa and South America better than the hypothesis of collapsed bridges. But still he held back:

In my opinion, what stops me from adhering to Wegener's theory and admitting high mobility, the total mobility of the continents, is that I believe in a fact, ${ }^{10}$ the fact of permanence, on the constantly changing terrestrial coasts, of several characteristic deep features, which have been recognisable for hundreds of millions of years, at least since the beginning of the Silurian period. These features are: first, the existence of a Pacific domain, and a very special domain that I call the circum-Pacific zone; and second, the existence of a transverse domain, forming a half belt to the Earth and welding together, at its two extremities, with the circum-Pacific zone. This transverse domain was occupied for a long time by the sea - the Tethys - and is today marked by two immense mountain chains of very different ages, approximately parallel, and sometimes superposed even over large distances. (Termier op. cit., p. 193-194).

Termier clearly regarded his vision of the Earth, itself a personal theoretical construction, as a fact, a fact which was incompatible with Wegener's ideas. For him, the latter represented, at best, a theoretical approach which was certainly very nice to dream about, but susceptible to criticism and would soon be discredited. Most Swiss and Alpine geologists reacted in a similar way during the first presentations plate tectonics. They believed that their vision of how the Alps were formed was based on the direct study of landscapes, rocks and geological processes, a totally different approach, closer to the facts, than any theory proposed by scientists who, at best, only had a vague knowledge of the Alpine chains. They often judged that the new theory brought only very few elements which could help them to resolve their major problems. Even so, returning to Wegener, continental drift was clearly successful in explaining the paleogeography and morphology of continents, and its promise for explaining large-scale overthrusting during continent-continent collision could hardly be ignored by free and imaginative minds like that of Argand and a few others.

The reaction in Switzerland

At the beginning of the twentieth century, as the spiritual heirs of Deluc (1778) and de Saussure (1779), geologists working in the Alps were convinced that the progression of knowledge related to the history of the Earth was intimately linked to the exploration of mountainous regions:

It is mainly the study of Mountains that can accelerate the progress of the Theory of the Globe. The plains are uniform, we can only see the cuts of sediments and their different beds by excavations that are works of water and men: these means are grossly insufficient, because these excavations are infrequent, not widespread, and are only two or three toises at the deepest. On the contrary, high mountains are infinitely varied in their material and form, presenting large scale natural cuts in the light of day, where one observes with great clarity, and at a glance, the order, the location, the direction, the thickness, and even the nature of the bedrock of which they are composed, and the fissures that traverse them. Nevertheless, the facility that the Mountains provide to make such observations are in vain if those who study them do not know how to imagine these large features as a whole and in their larger context. (de Saussure 1779, Vol. I, p. ii).

Or as Gagnebin stresses (1950, p. 63): "Drawing this [geological] map is to attack all the problems by the only means that allows them to be rigorously resolved. The map is to the geologist what the beautiful mathematical formula is to the theoretical physicist,...it is from well made geological maps that most of the discoveries in our science are 
conceived". Trümpy (2003) has pointed out, for instance, that this attitude explains the lack of interest that the Swiss geologists showed for a long time in sedimentology and for theoretical approaches in general.

From 1920 to 1950, the content of Eclogae Geologiae Helvetiae (the journal of the Swiss Geological Society, now called Swiss Journal of Geosciences) shows that regional geological studies supported by detailed mapping were central to what was demanded of young researchers. As Wilson (1982) remarks: "Geological mapping became both the method and the aim of geological research". With time, the scale of the structural zones studied tended to decrease to allow a gradually more careful and detailed approach. This basic methodology, essential to all geological research, developed observational expertise and a deepened insight into small-scale geological features and processes. At the same time, however, too often, it led to a limited view of geological phenomena, from which it had difficulty in encompassing larger-scale features of the Earth-continents, mountain chains, sometimes even the immediate surroundings of the particular mapping area. The important task of the geological mapping of the continents, particularly the mountain ranges, continued throughout the twentieth century, but the research that led to the finalisation of plate tectonic theory was carried out in the oceans, mostly employing geophysical means to study objects that the scientists practically never touch or see. Contacts between structural field geologists and geophysicists and oceanographers were not easy and the gap could not be closed without patience because both groups had different aims and training. On the one side geologists were studying rock complexes to unravel parts of Earth history, on the other side, the geophysicists and oceanographers, with their physical equipment, were trying to present the actual physical state of the interior of the Earth and the ocean floor.

Against this background, the reaction in Switzerland to the new hypothesis was cool or uninterest. Nevertheless, two geologists of the time, the young Elie Gagnebin and the experienced Emile Argand, took continental drift seriously, in each their way.

\section{Gagnebin's critical analysis}

In Switzerland, Elie Gagnebin published an important and detailed review, the first critical analysis of Wegener's theory (Gagnebin 1922, see also Carozzi 1985). He was 30 years old at the time, and as a student and collaborator of Lugeon at Lausanne, he had just defended his doctoral thesis, a regional study of the frontal Prealps, near Montreux. It is surprising that such a young author dared to take on such a challenge, even though the responsibilities that
Lugeon had given him and also his artistic activities already had made him relatively well known. Nevertheless, one could wonder whether this article was a request from his employer, for whom he had great esteem, or whether it could have been an invitation from Argand, who at this time was often in Lausanne. Neither of these possibilities seem credible, however, especially the latter: in the introduction of the article, Gagnebin shows that he is unaware of the fact that Argand had been called upon by the International Congress of Geology in Brussels to present a talk on the tectonics of Asia, which was greatly inspired by the works of Wegener. Gagnebin's thorough analysis was published after his stays in Grenoble in 1919, with Killian, and in Paris in 1920, with Haug. It is perhaps in these cities that he came into contact with informed colleagues. However, also this possibility seems unlikely, because he writes:

In France, where the theories of Einstein and Freud are so furiously in fashion, Wegener's hypothesis is almost completely ignored ... It is a maddening omission. Because if Wegener's idea is open to criticism from more than one point of view, if the reservations about it are imposed, we can neither ignore it nor let it pass in silence. (Gagnebin 1922, p. 293).

A further possibility is that Gagnebin could have met Juvet ${ }^{11}$ in Paris, who had studied in Neuchâtel, and was informed of the interest that Argand brought to these questions. These are speculations. What seems indisputable is that Gagnebin's article was the reflection of his own thoughts as well as having been influenced by discussions with many geologists, mostly Alpine, whose critical attitude comes out clearly in his presentation:

I insist that Wegener is only a second rate amateur geologist; we must accept his clumsiness, and control ourselves from crying out when it is apparent. It is not certain that the apparently nonsensical parts of his theory need to condemn the fundamental idea, nor even that they are great importance... Wegener has a systematic mind and is a geophysicist. During the first exposition of his theory, he supported it using generalisations about the Earth's crust, doctrines which geologists have learned to distrust. It is that which is the weak point of his argument, and certainly the 'proof' that he brings from geophysics will have difficulty being heard in France... Wegener begins with isostasy; to him, it represents more than a group of facts, it represents a system of physical necessities outside of which one cannot imagine the state of the terrestrial globe... I think that, above all, it is necessary to carefully establish a clear distinction 
between the fundamental idea, on the one hand, that is to say the drift of continents, their agglomeration in the past in masses different from ours, the absence of collapsed continental bridges, the displacement of the poles, etc., and on the other hand, the premature ideas that touch on orogenesis, the constitution of the Earth's crust, isostasy, etc. Wegener's error is to want to explain everything. Among natural phenomena, and especially geological phenomena, there is little to which one can assign purely physical causes. It is necessary to establish the reality of the facts before wanting to know the cause. This is the case, for example, for the nappes structures of which our mountains are formed. "One often refers to this discovery as the theory of the large nappes. In reality, it is not a theory, it is the expression of an observational fact, whereas the theory, that is to say, the explanation, is still very far off". ${ }^{12}$ (Gagnebin 1922,).

\section{Argand and continental drift}

Emile Argand $^{13}$ seems to have been acquainted with Wegerner's theory even before 1915 when he gave his talk at the Natural Sciences Society of Neuchâtel. The very short summary of it, as reported in the proceedings of this meeting (Argand 1918) gives a poor indication of the content of this speech: "M. Argand explained ... the modern views on the origin of the Continents and the Oceans. He described the theory of Wegener, who is trying to replace the hypothesis of collapse by that of dislocations. This new concept explains much better than the old one the similarities of flora and fauna between the regions separated by vast oceans today; it is supported by the study of glaciations at the end of the Primary Era". The local newspaper was no more explicit in commenting Argand's presentation, adding only that it was so brilliant that he made his listeners visualise the continents as floating around like rafts...

Argand quickly became a defender of continental drift in his lecture courses, as recorded in his correspondence with Gignoux and in the talk cited above (Argand 1918). Despite this early conversion to Wegener's ideas, the first mention in his publications of the works of Wegener only appears in La Tectonique de l'Asie (Argand 1924b, p. 289). There, reference to them is only made after more than a hundred pages, many of which carry the undeniable mark of this influence. If Wegener places the heart of his arguments on the evolution of the Atlantic, and the ocean domains and their borders, Argand on the other hand, illustrates the richness of the new theory essentially by applying it to the collision of moving continents, mainly those of Asia, and to the formation of the Alpine-Himalayan mountain chains originating from the evolution of the Tethys and the Mediterranean.
The idea of continental mobility was already present in his work "Sur l'arc des Alpes occidentales" ("On the Western Alpine arc", Argand 1916), which begins as follows:

Similar to a whole directed movement following the meridian, at least close to it, the ancient horsts of Europe and Indo-Africa have initiated the formation of an almost plastic flow in the geosyncline domain and in the sandwiched zone of the Tethys, which ended by the surge of a double set of mountain chains, nappes, and folds, pressed against the jaws of the vice, thereby called to act as foreland. (op. cit., p. 145).

One section of this publication bears the heading "Drift", in which Argand examines the flow of napps in relation to obstacles and the problem of virgations, areas of strong changes in strike, as though the nappes were wrapped around more rigid crustal blocks. This theme would be developed further in La Tectonique de l'Asie. At around this time, Argand envisaged only modest displacements of continents, in order to avoid any temptation of overstatement. He even opposed inappropriate ideas derived from the unfolding of the perimeter of large recumbent folds, which by their very obvious stretching, especially of reversed limbs, can lead to exaggerated values of shortening.

In 1920, Argand gave a lecture at the general meeting of the Swiss Society for Natural Sciences, in Neuchâtel, which provides a kind of prelude to his classic work, $\mathrm{La}$ Tectonique de l'Asie. It has a powerful and lyrical style. In it, he stresses particularly the vivifying effect brought to geologists by the research of tangible objects:

The Earth, is it not, after all, the only inorganic system of some importance that we can touch, and does it not enjoy on top of this palpable advantage a variety, a beauty, a complexity that impresses itself on all our senses and creates an even greater fascination and attraction? ("La Terre n'est-elle pas, tout compte fait, le seul système inorganique un peu important que nous puissons toucher, et ne joint-elle pas, à cet avantage palpable, une variété, une beauté, une complexité qui la désignent d'autant plus à notre attention, que nous lui gardons un attachement plus forcé ?" Argand 1921, p. 13).

Knowing that oceans cover three quarters of the planet and that the continental crust hides what is underneath "there is much to hope for, for tectonics and progress in understanding the physics of the globe, and physical chemistry applied to the evolution of magmas" (op. cit., p. 13). The improvement of geological knowledge of the Alps leads him to create a model that should facilitate the 
exploration of other parts of the world: "We have seen...how the knowledge of the Alps, which has revealed so many secrets and which is still keeping some, can shed light on and modernize the knowledge of many other chains. Let us salute the Alps, guarantor of fertility for our science!" (op. cit., p. 39). More than ever, Argand's message at this time seems to be influenced by the great tradition of Alpine geology, in which the scientist still has intimate contact with the rocks and the landscape.

\section{La Tectonique de l'Asie (Argand 1924a, b) and Carte Tectonique de l'Eurasie (Argand 1928)}

Argand's major scientific work, La Tectonique de l'Asie (The Tectonics of Asia), is supposed to have been the written version of the paper he presented at the International Geological Congress in Brussels, in August 1922 (Argand 1924b). With its 150 pages of text, however, and the accompanying Carte Tectonique de l'Eurasie (Tectonic Map of Eurasia) which was published later (Argand 1928), it must have been considerably extended after presentation. Its final editing took place in Lausanne, at the home of Lugeon, who claims that at the beginning of the work, Argand was still more or less a fixist. Lugeon maintains that he, Argand, was converted to the concept of mobility that colours the entire work by his, Lugeon's, remarks (Lugeon 1940). Argand's previous writings leave serious doubts about this assertion. However, it can be assumed that during the finalisation of the manuscript, and the conversations that accompanied it, Argand's thinking evolved towards a mobility that was more and more marked (see also the remarks by Sengör 1998, p. 86 and the end of note 121).

Before La Tectonique de l'Asie, Argand published a brief text (Argand 1924a), in order to insure that his work took precedence over Rudolf Staub's Bau des Alpen (Structure of the Alps, Staub 1924). Argand was concerned that the latter would contain information he gave to his old friend, Staub, in confidence, when he had earlier stayed in Neuchâtel for several months, for inspiration. Argand's mobilist leanings appear clearly in this short publication: "This penetration of Africa into the heart of Europe, i.e. into the Alps...seems to me inexplicable without immense continental displacement, even more so because the amplitude of the thrusting ... is enormous" (Argand 1924a, p. 234). Argand believed that the African promontory, which is wedged far into Europe, was ripped off from the rest of the African continent, as Europe continued its northward drift. Behind it, the continental crust, stretched by the drift, split apart, forming the Ionian Sea. He saw the latter as an extensional suture, in which the sima appears at the level of the ocean floor. Starting from this new situation, it would have been natural to imagine that an accelerated drift from Africa would have taken place, and it would have been difficult for Argand to consider, as he already did in 1916, that this ophiolitic suture was a magmatic injection placed between the sediments of the two continental borders during collision. For once, Argand was not the visionary, capable of going beyond his own models. In this short paper, he only thought of being the first to expose the consequences of the great overthrusts that are produced in the mountain chains between Africa, Europe, and Asia, and to relate these to several details of the evolution of the Mediterranean Sea.

La Tectonique de l'Asie (Argand 1924b) and the Carte Tectonique de l'Eurasie (Argand 1928) formed an incomparable set, which received an admiring welcome, not only because of the broadness of the synthesis, written singlehandedly, but also because of the elegance of the writing and the beautifully drawn map. Unfortunately, this remarkable artistic exercise was not accompanied by equivalent didactic qualities. Argand did not aim at the finalisation of a solid theory that can easily inspire. The pair constitute a research report, rich in new proposals aimed at being tested by future studies. The language used, including the introduction of numerous neologisms, not always very well defined, makes its reading difficult, even for a francophone. There is an abundance of localities cited that are not located on the accompanying maps. Another major inconvenience of this work is the almost total lack of references that would give access to the studies used in the elaboration of regional syntheses. Although often cited, and in spite of a modern English translation (Carozzi 1977), it is in fact rarely read in its entirety, and even more rarely assimilated.

Although at this time several American researchers considered that all deformations recorded on Earth were the result of vertical displacements, Argand (1924b) showed that, at the continental level, everything was the result of horizontal displacements: "We shall see that there are no vertical movements that cannot be considered as the direct or indirect effects of deformations in which horizontal stresses are usually predominant." (op. cit., p. 176-this and later quotations are taken from Carozzi's English translation of $\mathrm{La}$ Tectonique de l'Asie, but the page references are for the original French edition, as indicated by Carozzi). "There are certainly isostatic movements. But with respect to their possible distribution as the immediate vertical effects of folding, I shall demonstrate that in spite of initial appearances not one is known that may not be related, directly or indirectly, to deformations in which horizontal effects prevail or have prevailed" (op. cit., p. 219). Whereas the attention of the geologists of that time had been focussed on the 
deformation of cover rocks, Argand introduced the concept of basement folds, implying that, during the collisions, the deformation takes place over the whole thickness of the crust, the overthrusting also affecting the older bedrock. "In all the continents... the basement folds predominate by their tonnage, and even more by the energy they consume, over the new chains, whether the latter arose from geosynclines or simply from monoclinal slopes facing the open sea" (op. cit., p. 267).

The book takes into consideration the deformations of the whole of the Earth's surface by paying particular attention to those of Eurasia and the Tethys. The analysis is conducted in three dimensional space, integrated in time. Morphological data are often used by Argand to provide a visual image of the deformation. "The island arcs, the island festoons and the ordered chains that are displayed by the present face of the Earth have reached very variable degrees of development or of reworking. These moving objects have the admirable property of showing side by side, at this instant in time, all the transitional aspects that one of them can display during its own history. What a spectacular example of comparative anatomy and what an unusual museum of tectonic embryology! One perceives great lessons to be drawn from such an important fact." (op. cit., p. 177).

Argand recognizes that "almost nothing is known about the forces responsible for continental drift, but one should admit in addition to a passive transportation of the sial by the currents of the sima, movements proper to the former with respect to the latter." (op. cit., p. 326). Thus, in contrast to Wegener, Argand envisaged that the terrestrial dynamic is partially governed by displacements originating at great depth. "Thus, the energy is distributed, on the upper scales, in massive flows that divide themselves, on the lower scales, in streams and in increasingly smaller rivulets. Naturally, these visual metaphors do not clarify a physical theory of the distribution of energy. But correct visions can, if necessary, do without theoretical ballast; whereas the theories cannot succeed without a correct initial vision." (op. cit., p. 327).

\section{Argand and ophiolites}

In his 1916 paper, Argand had provided his vision of the locations of the "green rocks" and the mechanism by which they are emplaced, in long explanatory commentaries accompanying the diagram of an Alpine-type mountain in its embryonic state (shown here as Fig. 4, of which the following is Argand's explanation).

The principle path of adduction for these magmas is the reverse limb of the nappe of the Dent Blanche, which is still occupied today by a vast laminated and recrystallized gabbro sill ('Tracuit group'). No continuity is preserved in the reverse limb. The magma brought towards its front since the early embryonic time, uses, as soon as it has arrived, the small décollements that tend to be produced there in great numbers producing a series of clusters relaying each other. Thus, the basic rock occupies, step by step, all the parts of a system of interconnecting chambers both vertically and laterally. The injection, which is of a Mesozoic age and can also be in part Tertiary, not only reaches the reverse limb zone, but also penetrates the neighbouring parts of the nappe and the substratum. In the nappe, intrusive structures, veins and small laccoliths, preferentially infill the hinges of anticlinal digitations .... In front of the embryonic island chains (cordillera),...., sub-marine volcanic effusions take place at the outlet of clusters of tectonic décollements. In total, the location of green rocks, as much at depth as on the surface, appears related to the embryonic tectonic. (Argand 1916, p. 186).

In Argand's mind, the role of ophiolites in the overthrusts of the Pennine zone and, by extrapolation, of the Himalaya, was most certainly influenced by Suess's note (1904), written in French, whose importance and oversight have been the basis of useful commentaries (Sengör 2003a, p. 407-408, and pers. comm.). The idea that basic intrusions could act as a lubricant to facilitate the overthrusting in collision zones has also been advance by other authors. For several decades, the reservations expressed by Holmes (1930, p. 177) on this subject during his stay in Switzerland have been ignored. Except for the common association of radiolarites (deep sea sediments) and ophiolites (mafic lavas, gabbros, serpentines) already recognized by Steinmann (1905), Argand had no valid proof for placing these rocks and their chronology in a coherent evolution. He substituted a model of intrusions and deformations that negates many of his observations, but which integrates perfectly into the process of embryonic evolution that he wished to promote (cf. Sengör and Okurogullari 1991, p. 543). Later on, he seems to have become conscious of the differences existing between his interpretation and his observations in the field. His representation of continental Eurasia-Gondwana collisions indicated by a suture marked by basic rocks (Argand 1924b, Figs. 16-18, here reproduced as Fig. 5), again inspired by Suess (1904), remains a symbol of his visionary thinking. He remained discrete concerning the reasoning which that led him to this solution, although conscious of the hypothetical nature of this wonderful but audacious proposal. Already in his previous work (Argand 1924a, p. 235), he had described in detail the crustal thinning of the African promontory, as shown later (cf. Fig. 5). 


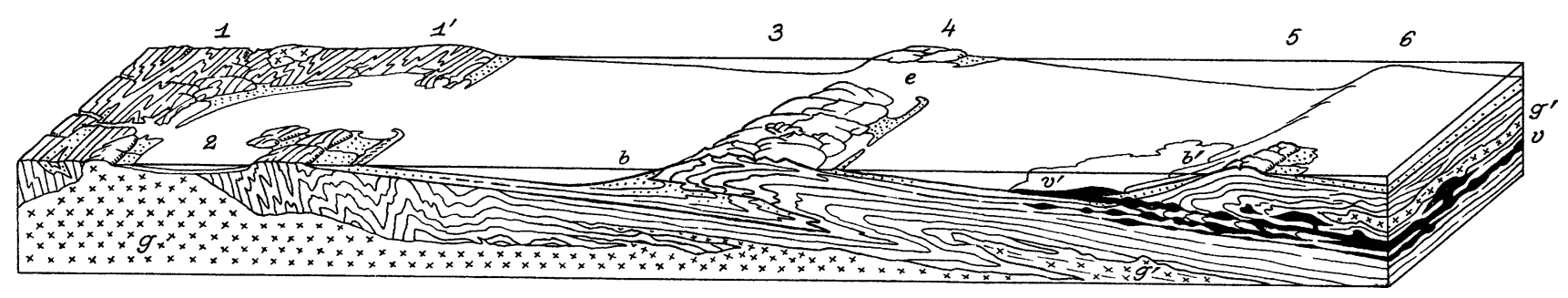

Fig. 4 Rise of basic magma along thrust planes at the beginning of orogenesis, as proposed by Argand (1916, Plate 3, Fig. 1). The concept was later referred to as "embryonic tectonics". The basic rocks are associated with the main zone of thrusting, intruded in the form of sills and laccolitic bodies, rising along the developing inverted limb of the thrust nappe
Sketch B (after disjunctions) shows the importance of these shears and the stretching caused by the northward drift of Europe, after the paroxysm of folding. The lowering of the heights of the sialic crust, resulting from the lenticular segmentation of the continents, leads to the reappearance of a deep Mediterranean. ...The mechanism of the emplacement of basic rocks along the base of the great moving nappes, and the theoretical link of these rocks to their place of origin, in the sub-continental sima, are indicated. (op. cit., p. 235).

Nevertheless, the emplacement mechanism of these basic rocks in the upper parts of the continental crust is never discussed. Perhaps, having some doubts about his previous contribution (Argand 1916), he linked the suture marked by the ophiolites to the phenomenon of oceanisation, and, in agreement with Wegener's sketches (Fig. 3d), he introduced the idea of extension in the geosyncline's evolution. The image of a mountain chain as linked to a single and continuous contraction (Argand 1916) was so strong and so successful that this new proposal went mostly unnoticed by Alpine geologists, until Masson (1976, p. 558) mentioned the existence of this concept in $\mathrm{La}$ Tectonique de l'Asie. Sengör (1982) also stresses the importance of the idea of crustal extension as an element in Argand's thinking, especially in his last work (Argand 1934). Long normal Mesozoic faults, parallel to the Alpine strike, noted by Günzler-Seiffert in the Helvetic zone of the Bernese Oberland already in 1932 (cf. Günzler-Seiffert 1952) have long been ignored, even though they are clearly observable and perfectly explainable. Later, they were rehabilitated by Trümpy in his 1960 review of the status of Alpine geology (Trümpy 1960), associating them with those observed in the Briançonnais, first by Lemoine, and later by other scientists in different parts of the French Alps. In La Tectonique de l'Asie, Argand propounds the extensional view as follows:

A geosyncline will generally result from a horizontal traction (underline by Argand) that stretches the raft of sial. The stretching is at first easier in the deeper part of the sial rather than in the upper part, where extension fractures may develop. While thinning, the sial sinks and develops a depression: the subsidence inherent in the geosynclinal process does not, therefore, stem from an original radial stress, it is only the vertical effect of an horizontal distension. The overburden of the deposits helps, of course, to accentuate the alveole, but the latter is not necessarily the original feature. Until compensation, the sima rises under the thinned sial; this behaviour accounts for the frequent association of green rocks with bathyal and abyssal sediments. The mixture of abyssal with shallower sediments takes place through sub-marine sliding on the slope"... "If traction continues ... the sial continues to stretch and the sima appears at the bottom of the alveole. Along the transverse alignments where such a situation occurs, the geosynclinal condition is replaced by the oceanic condition. (Argand 1924b, p. 299). ${ }^{14}$

His idea of extension reappears in 1934: "A geosyncline forms by distension and its future evolution is controlled by alternating compressions and distensions, until the last compression, which is its paroxysm" (Argand 1934, p. 182). In this way, the complex sedimentation on the oceanic crust with abyssal sediments and turbidite deposits mixed with green rocks and other sediments of shallow depth is vision already present as early as 1924 . He indicates further that if compression replaces traction, it is here that the folding will first manifest itself. He perfectly illustrates the evolution of the ancient suture separating two continental masses that collide (Argand 1924a, Fig. 1; Argand 1924b, Figs. 13-19). Although Argand seems to be proposing solutions which would be accepted at the present time, he continues to believe in the intrusive nature of the basic rocks (Argand1934, p. 160). In the region of Zermatt, Güller (1947) and Bearth (1967) are credited with having recognized that the ophiolitic masses associated with chaotic sedimentary material are independent thrust slabs. 

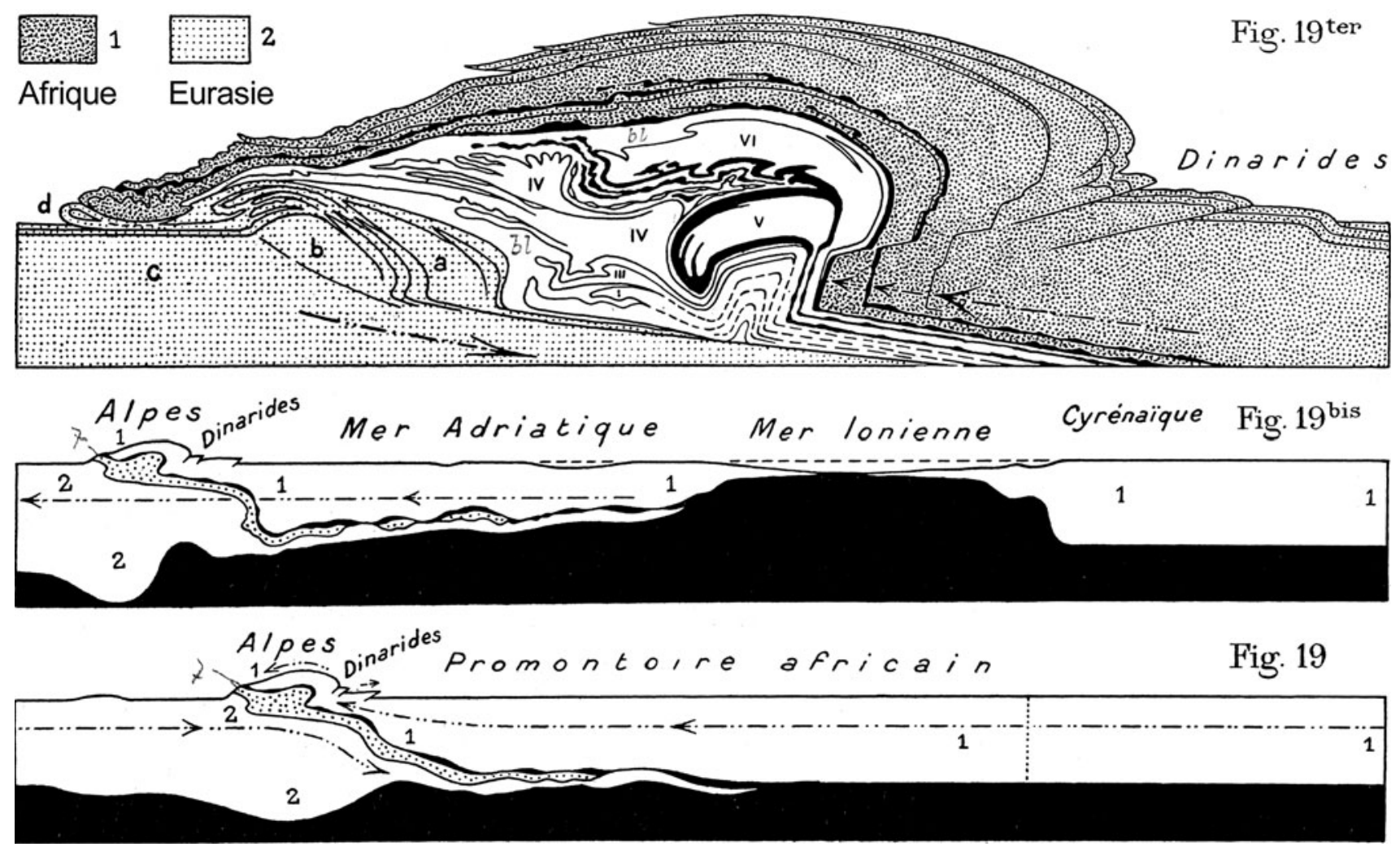

Fig. 5 Illustrations from La Tectonique de l'Asie (Argand 1924b), showing a detailed reconstruction of the structure and kinematics of the Central Alps (upper profile) and two more generalised crustal profiles across the Alps and the Mediterranean Sea (lower profiles). In the general profiles, the suture between Africa (1) and Europe (2) is marked by the occurrence of basic rocks (ophiolites) derived (intruded) from the ancient ocean Tethys. Fig. 19 ter.: Basic rocks (in black) present at the base of the Austroalpine system (Africa) and

Bernoulli et al. (2003) and Bernoulli and Jenkyns (2009) give the background to the problems related to ophiolites in the context of the geosyncline and its evolution in the Alpine chains, intimated in the early works of Steinmann. These authors show that the majority of ophiolites in the Alps and the Apennines should be considered as incomplete ophiolitic series derived from continent-ocean transition zones or from slow spreading ridges: "The mantle material has proved to be derived from the subcontinental mantle rocks exhumed along a system of detachment folds exposed on the sea bed" (Bernoulli and Jenkyns 2009, p. 378).

Sartori (1990) recognized that Argand's mapping can hardly be improved. His ambiguous relationship to ophiolites and their emplacement is linked to two major handicaps, compared with today's situation. Firstly, a good part of his reasoning is based on the existence of a reverse limb during the initial ("embryonic") development of the Pennine nappes, which recent research has not confirmed. Secondly, the geology of his time did not offer him in the Mesozoic of the Piedmont trough - these and some sediments led to Argand's concept of "embryonic tectonics". These rocks are wrapped into the large Pennine folds, with sills and laccolites forming in the inverted limb of the Dent Blanche nappe, prior to the Oligocene paroxysm. Fig. 19bis, locates, in the middle of the Ionian Sea, the beginning of oceanisation by distension brought about by the northward drift of Europe

concepts for the genesis of the ophiolitic zones to be incorporated into his models. To remedy this lack of information, he returns to the idea of intrusions proposed by Suess (1904), even though this proposition was not supported by precise observations, neither by him nor by other geologists. Despite these insufficiencies, for almost a half a century, this vision remained the uncontested framework for the proposals concerning these areas. Nevertheless, by stressing that "the validity of a theory is nothing else but its capability of accounting for all the known facts at the time it is presented" (Argand 1924b, p. 292), Argand knew that he was only offering a passing look to the scientific world.

The few weaknesses of Argand's models have never been used to discredit his adhesion to hypothesis of continental drift. Conversely, the defenders of plate tectonics do not make precise allusions to his vision of large ophiolitic sutures nor did they refer to his proposals of oceanisation combined with gravity sedimentary discharges. In the world of geophysics, data resulting from 
fieldwork that geophysicists do not always understand and therefore do not trust, often get little credit. History treated Holmes' new proposals differently: his work, published in English, with a firm physical basis and clearly formulated, was more immediately convincing.

Argand and geophysics

Like the other Alpine geologists of his time, Argand was often reticent when confronted with geophysical data. He never commented on the arguments used by Wegener to defend his thesis. However, Thalmann (1943) reports that in 1919 Argand said "Geology is a science of the past; the future is geophysics". This quotation is similar to a thought recorded at the beginning of La Tectonique de l'Asie: "I do not pretend to reduce tectonics to physicsthis is a matter for the future" (Argand 1924b, p. 172). Nevertheless, in his reflections on the folding of the Earth, gravimetric measurements are used to support his vision of large structural assemblages. He notes that "we have three orders of facts whose synthesis is one of the major problems for the future: observable tectonics, gravity anomalies, and isostatic behaviour" (op. cit., p. 272). These lead him to forcefully reject the idea that the ocean floors could include subsided continental fragments: "I consider this proposition to be totally incompatible with isostasy" (Argand op. cit., p. 290). Even though he accepted the idea of displacement of matter in the sima, he associated the gravimetric variations mainly with variations within the sialic crust. In the great continental masses, "consideration of the gravity anomalies, in the light of the visible tectonics, [has] a great interest. The dangers often presented by the inverse process, by means of which one attempts to interpret the visible tectonics through the anomalies and through a conjectural infratectonics in order to explain the best known by the least known,...result...from the multiplicity of possible explanatory combinations" (Argand op. cit., p. 281). He is aware that in Europe the profusion of structural details does not facilitate the interpretation of gravimetric data. However, in the USA, data collected by Bowie (1917) had demonstrated the correlation of morphologic swells, basement folding, and negative anomalies. The latter, appearing to be skewed eastward in relation to the morphology, become for Argand another proof of the continental drift in the direction of the Pacific. He ignores the proposals of Barell, almost contemporaneous (cf. Oreskes 1999, p. 182-189), which placed the compensation underneath the continental zone, in the most ductile zone (the future asthenosphere). Had he known this propositions, would he have taken them into account? Probably not, as they gave too much importance to vertical movements, defended by this author.
Argand and knowledge of the oceanic domain

At the time of Wegener's publications, the knowledge of oceans was still in its infancy. Argand followed the development of this discipline with interest; he bought more than forty important publications on the subject between 1915 and 1930. In La Tectonique de l'Asie, he uses the bathymetric maps of Murray and Hjort (1912), although still quite primitive. With these, he compares the Mid-Atlantic Ridge "to a wreck of sial tossed around and deformed in the sima, apparently the heritage of the time in which the New World was beginning to separate from the Old" (Argand 1924b, p. 311). This proposal that the MidAtlantic ridge represents a continental fragment was later supported even by many defenders of continental drift, for example Holmes (1929) and Daly (1942). The several E-W topographic anomalies which ran from one side of the ridge to the other at the level of Newfoundland seemed to be well enough established that Argand considered them to be "the elongated, stretched, thinned out, and consequently depressed remains of the basement folds that extended from Cornwall and the Armorican massif to Newfoundland, the Taconic chain, the Appalachians, and the Piedmont, across the segment today distended, collapsed, and abandoned" (Argand op. cit., p. 312). In this case, all the evidence is retained, even the smallest, when it concurs with his convictions. It is the defence of a cause, rather than the presentation of data that has passed the filter of fair criticism. With regard to the Pacific, Argand remarks: "We cannot see anything of the substratum of the Great Ocean, but we cannot doubt that the behaviour of the Circumpacific chains depends to a great extent on the nature of this substratum" (Argand op. cit., p.293). He thought that the complexity of the Alpine chains has been greatly influenced by the heterogeneity of the continental blocks involved in the collision. In contrast, those of the Pacific border encountered in Asia, offer a simplicity that "disclose the presence, or predominance, beneath the Great Ocean, of a more homogeneous...medium... Therefore, there is no collapsed Pacific continent and, consequently, no circumpacific geosyncline" (Argand op. cit., p. 295). Along the borders of this homogeneous ocean, formed of sima, the marginal chains "arise from the freshly deposited sediments, either neritic or bathyal. These sediments are accumulated in great thicknesses on the continental slope and sometimes at its foot, as the consequence of submarine slumpings that are responsible at great depths for the repeated intercalations and the mixture of these deposits with the abyssal sediments" (Argand op. cit., p. 295). Despite his still somewhat summary knowledge, his vision of the ocean borders and their evolution seems much closer to what we know today than it is to the concept of the geosyncline, which would dominate geology for a long 
time into the future. As an Alpine geologist, fed by this last notion, Argand cannot convince himself to abandon it.

\section{After La Tectonique de l'Asie}

In 1919, the economic situation of the Canton of Neuchâtel became difficult. Despite this drawback, Argand's efforts and reputation allowed him to obtain a new and very spacious Institute of Geology. In the following years, as he was finalising La Tectonique de l'Asie and the Carte Tectonique de l'Eurasie, the worsening economic conditions of the region provoked severe criticism of the University's spending. The Institute of Geology was especially implicated due to its high running expenses and its small number of students, who did not find work locally. Argand had to defend himself, but he successfully managed to preserve the institution that he had created. Nevertheless, he was forced to dismiss his teaching assistant, Alphonse Jeannet, and to abandon all ambition of new support. It is difficult to judge to what extent this circumstances influenced his behaviour and led him to gradually abandon geology, which had served him so well up until that time. The difficulties that he experienced in finalising his two major monographs (Argand 1924b, 1934) show that he had lost the enthusiasm that characterised him up to then (Staub 1940). Was his decrease in productivity due to a premature and generalised fatigue or were some other external conditions to blame? Without any hard proof, we think that the latter explanation is the less credible.

An analysis of the literature published after the appearance of La Tectonique de l'Asie shows that, during the author's lifetime, it was only translated once, into Russian in 1936. It seems never to have had much impact and seems not to have inspired further ideas. One might even think that the effort had been fruitless, not having influencing the development of geology in general and the Alpine chain in particular. It was not until plate tectonics arrived on the scene that part of its potential was finally recognised, although only in a historical context. To understand why this could be, all we have are hints as to what may have held back further development. After 1924, Argand almost entirely abandoned geological research (Schaer 1991), even though he continued to teach. ${ }^{15} \mathrm{Hav}-$ ing presented his major contribution, he probably experienced the fatigue brought on by the colossal creative work that he conducted singlehandedly for over two decades. To those who criticized him for never visiting the French capital, the centre of creative thinking, he responds ironically: "It's true, but I am in Neuchâtel and it is here that geology is being built". Unwavering, conscious of the value of his past productivity, he remained persuaded that the truth always triumphs and that his genius, already recognised by certain individuals, would soon be recognized by everyone. He gradually isolated himself inside the small circle of admirers that he had created. Borel, one of his biographers, evokes perfectly, with several traits and anecdotes, sometimes cruel, the mood of the tired but proud savant. For instance, "One evening when we were going out to eat, my mother and I, at the Café du Théâtre, who do I see, marching with a lively step in the square? Argand. 'Look, mother', I say immediately, 'there's Argand'. My mother looks, and straight away, with the perfect common sense that is characteristic of her, she says, 'But surely, that must be Tartarin ${ }^{16}$ !" (Borel 1976, p. 147).

Whereas most scientists make an effort to insure the distribution of their ideas and the acknowledgment of their success, Argand seems to have ignored this practice, especially in the two last decades of his life, when he was careful to maintain his reputation only among his close circle of friends. He travelled a little, but generally waited for his colleagues to come to him rather than him approaching them. At Neuchâtel, the circle of scientists that he impressed remained active and insured his local glory. But the person who could have benefited from them did not support their initiatives. These actions, carried out by people unknown to active research, only had a small effect on the international scene. Wegmann, who dared to use the Master as guarantor in one of his papers, perhaps without having informed him, was dryly put in his place (Argand 1926).

At the end of the $1920 \mathrm{~s}$, the geological community was gradually becoming more critical toward Wegener's theory. Works directly inspired by it were particularly affected by this negative atmosphere. References to works by Argand, especially La Tectonique de l'Asie, became more and more rare. International meetings took up the question of continental drift, but because they took place mainly in English speaking countries, references to German or French non-translated works were scarce. Whereas Die Entstehung der Kontinente und Ozeane was first translated into English in 1924, La Tectonique de l'Asie had to wait until 1977 for the publication of an English translation (Carozzi 1977), well after its translation into Russian in 1935. At the time of its publication, Argand's work was the object of very favourable comments, for example by Bailey (1926), who noted its exceptional scope and placed it in the lineage of The Face of the Earth, by Suess (1921). Many of the best researchers at the time were astonished by the elegant, grandiose effort, executed singlehandedly. However, the innovative proposals that it contained were often ignored, because they were too often included in lengthy explanations, demanding great effort to read. Only a few scientists really knew his work, particularly the nonfrancophones. In addition, Argand did not address the mechanism or mechanisms required continental drift and he was not active in oceanography or geophysics. These 

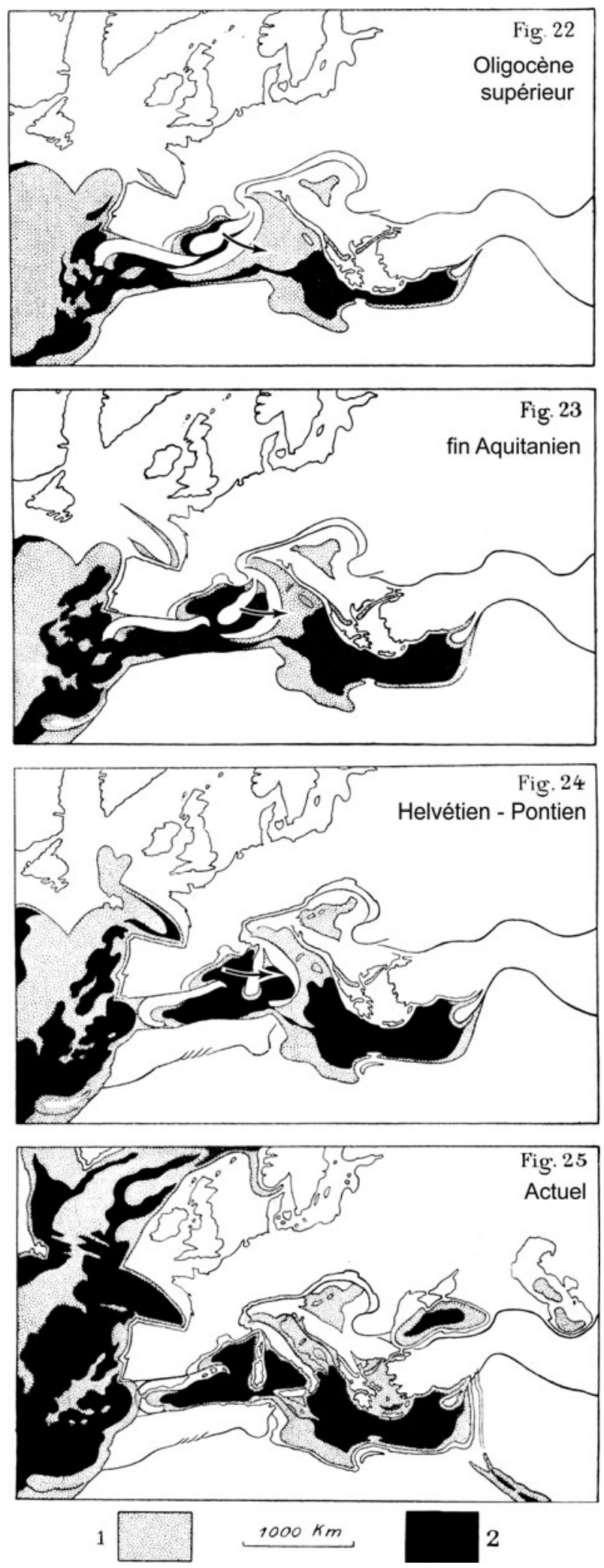

Fig. 6 During the opening of the Atlantic, oceanisation in the Mediterranean Sea, due to crustal distension associated with the rotation of the Corsican-Sardinian block (Argand, 1924b, p. 356-359). Legend: 1 Sima, attentuated; 2 Sima, more attenuated than 1 , locally missing drawbacks put his theories in a perspective that separates it from the problems that were becoming dominant. Although Holmes applauds Argand for his analysis of complex structures of the Mediterranean with the rotations of Corsica and Sardinia (Fig. 6), he is one of the rare authors to stress how much this ingenious proposal could appear strange in 1924. It can also be noted that many authors had real difficulty in comprehending the nuances of Argand's tectonic ideas. They would have preferred straight simple propositions than to be driven through the subtlety of Argand's meandering thoughts. "Personally, I never feel safe of my foothold when I try to follow Argand into the dim recesses of the past; but this does not lessen my admiration for a guide who has opened up so many secure routes through the hitherto almost trackless Pennines" (Bailey 1935, p. 126).

Acknowledgments Many colleagues and friends have given their generous support during the preparation of this contribution and have provide me with very useful information. Amongst them, I especially wish to mention N. Ray, N. Pavoni, J. Gaudant, the late M. Lemoine and the late R. Trümpy. My special thanks are due to C. Sengör who with his usual enthusiasm examined and corrected a first version of this paper, written in French. This was later translated into English by Karin Verrechia. A. G. Milnes deserves my special gratitude for his generous and long lasting help and patience in putting this contribution into a correct form, and also for his thorough review. At the University of Neuchâtel, where a large part of this work was carried out, I was fortunate to benefit from the help from Gianfranca Cerrito, Elisabeth Kuster, Sabine Erb and Philippe Renard. Again, many thanks to all.

\section{Notes}

1 In this paper, the citations from La Tectonique de l'Asie are taken from the English translation by Carozzi (1977).

2 The continuation of the present paper, which will appear later in the Swiss Journal of Geosciences, is called "Swiss and Alpine geologists between two tectonic revolutions. Part II: on the way to the theory of plate tectonics", and deals mainly with the period between 1930 and 1970.

3 Albert Heim (1849-1937), Swiss geologist, studied in Zürich and Berlin and was influenced in his early life by Arnold Escher von der Linth. Heim was Professor of Geology at the Swiss Federal Institute of Technology (ETH) Zürich, 1873-1911 and long-time Director of the Swiss Geological Commission (the equivalent of a geological survey). Great authority on Swiss geology and the structure of the Alps, his work culminated in the monumental Geologie des Schweiz (1916-1922). He was very active in public life in different areas, such as women equality, cynology, cremation and prevention of alcoholism, as well as applied geology and nature protection.

4 Sial: the name commonly used in the first half of the 20th century, proposed by Suess in 1909, for the upper layer of the Earth's crust, composed of rocks that are rich in silica and aluminium (essentially of granitic composition).

5 Sima: the name commonly used in the first half of the 20th century, proposed by Suess in 1909, for the lower layer of the Earth's crust, composed of rocks that are rich silica and magnesia (essentially of basaltic composition). It forms the lower portion of the continental crust, underlying the sial, and the whole of the crust underneath the oceans (oceanic crust). 
6 According to Staub (1928, p. 22), Heim, near the end of his life, would be converted to the idea of continental drift, despite his advanced age.

7 Pierre Termier (1859-1930), French geologist and mining engineer, Professor of Geology at the Paris School of Mines and Director of the French Geological Survey. He carried out geological research mainly in the Western Alps and was the author of several major contributions on the geology of the Alpine chains and the western Mediterranean. He was particularly influenced by the work of Suess and Bertrand.

8 Otto Ampferer (1875-1947), Austrian Alpine geologist and famous climber, long ignored by the international geological community. After his studies in Innsbruck, he joined the Austrian Geological Survey in 1901, where he remained, becoming its Director 1935-1939. A great field geologist, he mapped a large part of the Calcareous Alps of Tyrol. In structural geology, he is recognised for his theoretical approach; in 1906 he already rejected the contraction theory of orogenesis and in 1926 he proposed thermal convection in the mantel. Married with Olga Sander, sister of the famous Austrian structural geologist, Bruno Sander, father of petrofabrics.

9 Wladimir Köppen (1846-1940), Russian born meteorologist, climatologist and paleobotanist of German descent. He first studied botany in Russia and later in Germany (plant growth and climate). After serving in the Russian Meteorological Survey, he accepted a position with the Naval Observatory in Hamburg as meteorologist in 1873, where he stayed until 1919. Best known for his mathematical classification of climatic types.

10 Emphasis by Termier.

11 Gustave Juvet (1896-1936). After graduating in mathematics at Neuchâtel, but greatly impressed by Wegener's work, Juvet moved to Paris to complete his education by obtaining a French doctorate. There, he eventually assumed the mantle of publisher, publishing translations of numerous classical monographs in the exact sciences, and the first French translation of Wegener's book, "La genèse des continents et des océans", in 1924.

12 Gagnebin is quoting here from Termier (1921): Epilogue to La Face de la Terre by Ed. Suess; French edition, Vol. 3, p. 1715.

13 Emile Argand (1879-1940), Swiss geologist, Professor of Geology at the University of Neuchâtel 1911-1940). As a famous Swiss geologist and a striking personality, a wealth of biographical material exists, see particularly Lugeon (1940), Thalmann (1943), Carozzi (1977) and Schaer (1991).

14 Several pages before advancing these prophetic views, Argand presents another interpretation of a geosyncline, although very traditional: "The classical concept combined with that of basement folds certainly allows bold interpretations. Here is one that I have considered: the Mediterranean-type seas, the marginal seas, and the oceans are but basement synclines. These geosynclines of a new type, formed by lateral compression and becoming the location of more particular types of lateral compressions, generating chains, would unquestionably explain many features. In that respect one thinks immediately of all kinds of island festoons, of the Oceanides, and of the elongated crests that sinuate in the middle of the Atlantic and in the western portion of the Indian Ocean. This concept leads directly to the idea of the continuity and particularity of the universality of folding, which becomes the only major aspect. Indeed, considering from this viewpoint the closed environment formed by the entire planet, one encompasses in one swoop, and rightly so, the totality of the horizontal and vertical aspects of the deformation. It becomes completely useless to ask oneself if the radial movements follow or precede originally the tangential movements, and what their reciprocal relationships are. This question, debated by generations of geologists, is justified on the scale of small entities but is meaningless with respect to the whole. The incapacity of the plastic media to transmit, beyond a certain distance, an effective effort is not an insurmountable obstacle if one assumes for the upper part of the oceanic substratum the same kind of heterogeneity that is displayed so clearly by the continental substratum. Thus renewed, the classical concept would allow extensive enrichments, and a long time would elapse before these resources would be depleted. Unfortunately, in relation to all this, there is isostasy, and as we shall see, much more." (Argand, 1924b, p. 291). In light of the preceding text, these comments suggest a good parallelism between basement folds and basement geosynclines. They integrate perfectly into Argand's early ideas of "embryotectonics", by stressing that there is no point in separating the vertical component during the large tangential displacements. These proposals do not have the great inventiveness of the evolution of the geosyncline placed in a context of stretching continents at their edges. The old ideas abandoned, Argand wants to preserve a trace of it!.

15 In 1934, in the Guide géologique de la Suisse, Argand is again the author of a remarkable introduction to the geology of the Pennine region. However, the editors received his contribution only after repeated pressure, which escalated to threats.

16 "Tartarin" - an amusing, likeable and candid character invented by Alphonse Daudet, endowed with a tendency to bragging on an epic scale.

\section{References}

Airy, G. B. (1855). On the computation of the effect of the attraction of mountain-masses, as disturbing the apparent astronomical latitude of stations in geodetic surveys. Philosophical Transactions of the Royal Society London, 145, 101-104.

Ampferer, O. (1906). Uber das Bewegungsbild von Faltengebirgen. Jahrbuch des kaiserliche und königliche des geologisches Reichsanstalt, 56, 539-622.

Ampferer, O. (1926). Beiträge zur Auflösung der Mechanik der Alpen. 2. Fortsetzung. Jahrbuch des kaiserliche und königliche des geolologisches Reichsanstalt, 76, 125-151.

Argand, E. (1916). Sur l'arc des Alpes occidentales. Eclogae Geologicae Helvetiae, 14, 145-191.

Argand, E. (1918). Procès-verbal de la séance du 3 novembre 1916 de la Société des Sciences Naturelles de Neuchâtel: Vues modernes sur l'origine des continents et des océans. Bulletin de la Société neuchâteloise des Sciences naturelles, 42, 117.

Argand, E. (1921). Plissements précurseurs et plissements tardifs des chaînes de montagnes. Actes Société helvétique Sciences naturelles Neuchâtel, 101/II, 13-39.

Argand, E. (1924a). Les Alpes et l'Afrique. Bulletin Société vaudoise des Sciences naturelles, 55, 233-236.

Argand, E. (1924b). La tectonique de l'Asie. Proceedings of the 13th International Geological Congress, Brussels 1922, 171-372.

Argand, E. (1926). A propos d'un détail de la tectonique du Valais. Compte Rendu Société géologique de France, 18 janvier, 16-17.

Argand, E. (1928). Carte tectonique de l'Eurasie. Echelle 1:25'000'000. 13th International Geological Congress, Brussels 1922.

Argand, E. (1934). La zone pennique. Guide géologique de la Suisse III (pp. 149-189) Basel: Wepf.

Bailey, E. B. (1926). Structural features of the Earth. Nature, 117, 863-864.

Bailey, E. B. (1935). Tectonic Essays, Mainly Alpine. Oxford: Clarendon Press.

Bearth, P. (1967). Die Ophiolithe der Zone von Zermatt-Saas Fee (p. 132). Neue Folge: Beiträge Geologische Karte der Schweiz.

Bernoulli, D., \& Jenkyns, H. (2009). Ancient oceans and continental margins of the Alpine-Mediterranean Tethys: Deciphering clues from Mesozoic pelagic sediments and ophiolites. Sedimentology, $56,149-190$.

Bernoulli, D., Manatschal, G., Desmurs, L., \& Müntener, O. (2003). Where did Gustav Steinmann see the Trinity? Back to the roots 
of an Alpine ophiolite concept. Geological Society of America, Special Paper, 373, 1-18.

Bertrand, M. (1884). Rapport de structure des Alpes de Glaris et du Bassin houiller du Nord. Bulletin Société géologique de France, $12,318-330$

Borel, P. L. (1976). La symphonie intérieure. III Orgies philosophiques. Neuchâtel: Ed. Messseiller.

Bowie, W. (1917). Investigations of gravity and isostasy. U.S. Coast and Geodetic Survey: Department of Commerce. Special Publication 40.

Buxtorf, A. (1907). Profile duch das nordschweizerische Juragebirge, der Kettenjura als "gefaltete Abscherungdecke" aufgefasst. Bericht über die 30ste Versammlung des Oberrheinischen Vereigung zu Lindau, 29-38.

Carozzi, A. V. (1977). The Tectonics of Asia. In Emile Argand, (trans: Carozzi, A.V.) (218 pp.). New York: Hafner Press.

Carozzi, A. V. (1985). The reaction in continental Europe to Wegener's theory of continental drift. Earth Sciences History, 4, 122-137.

Dal Piaz, G. V. (2001). History of tectonic interpretations of the Alps. Journal of Geodynamics, 32, 99-114.

Daly, R. A. (1942). The Floor of the Ocean. Chapel Hill: University of North Carolina Press.

Dana, J. D. (1873). On the origin of continents. American Journal of Science, 2, 94-100.

de Beaumont Léonce, E. (1828). Notice sur un gisement de végétaux fossiles et de bélemnites situés à Petit-Cœur près de Moûtier, en Tarentaise. Annales des Sciences naturelles, 14, 113-127.

de Beaumont Léonce, E. (1829-1830). Recherches sur quelques-unes des Révolutions de la surface du globe. Annales des Sciences Naturelles, 18, 5-25, 284-417 and 19, 5-99, 177-240.

de Beaumont Léonce, E. (1852). Notice sur les Système de Montagnes. Paris: Bertrand.

de Saussure, H.-B. (1779). Voyages dans les Alpes. Neuchâtel: Samuel Fauche.

DeLuc, J. A. (1778). Lettres physiques et morales sur les montagnes et sur l'histoire de la terre et de l'homme, adressées à la reine de la Grande-Bretagne xxviii+226 pp. La Haye: Detune.

Fischer, O. (1889). Physics of the Earth's Crust (2nd ed.) (p. 467). London: Macmillan.

Gagnebin, E. (1922). La dérive des continents selon la théorie d'Alfred Wegener. Revue générale des Sciences, 33, 293304.

Gagnebin, E. (1950). Discours de M. Elie Gagnebin, Professeur de géologie. Discours d'installation, 1940-1947. Lausanne: Imprimerie Vaudoise.

Gaudant, J. (1995). La réception de l'idée de dérive des continents en France et en Suisse Romande: les enseignements d'une enquête. Mémoire Société géologique de France, 168, 129-138.

Gohau, G. (1991). Postface à La genèse des continents et des océans: théorie des translations continentales, Alfred Wegener, traduction A. Lerne (p. 233-256). Paris: Ch. Bourgois.

Güller, A. (1947). Zur Geologie der südlichen Mischabel- und der Monte Rosa-Gruppe. Eclogae Geologicae Helvetiae, 40, 39-100.

Gutenberg, B. (1939). Hypotheses on the development of the Earth's Crust and their implications. In B. Gutenberg (Ed.), Internal Constitution of the Earth. Physics of the Earth VII (pp. 177-217). New York and London: McGraw-Hill.

Hall, J. (1859). Introduction. In Hall, J., Geological Survey of NewYork. Palaeontology, 3, 1-90.

Haug, E. (1911). Traité de géologie. I. Les phénomènes géologique (pp. 538). Paris: Armand Colin.

Hecker, O. (1910). Bestimmungen der Schwerkraft auf dem Schwarzen Meere und an dessen Küste, sowie Aussgleichung der Schwerkraftmessungen auf dem Atlantischen, Indischen und
Grossen Ozean. Berlin: Zentralbureau für international Erdmessung, N.F. 20.

Heim, A. (1918). Das Gewicht der Berge. Jahrbuch des Schweizer Alpenclub, 53, 179-201.

Heim, A. (1919-1922). Geologie der Schweiz (Vol. 1, pp. 704, Vol. 2, pp. 1018) Leipzig: Tauchnitz.

Helmert, F. R. (1910). Die Schwerkraft und die Massenverteilung auf der Erde. Enzyklopädie der mathematischen Wissenschaften. Leipzig: Teubner.

Holmes, A. (1929). Radioactivity and earth movements. Transactions of the Geological Society of Glasgow, 18, 559-606.

Holmes, A. (1930). Radioaktivität und Geologie. Verhandlungen der Naturforschende Gesellschaft Basel, 41, 136-185.

Joly, J. (1925). The Surface History of the Earth (pp. 192). London: Oxford University Press.

Le Pichon, X. (1984). La naissance de la tectonique des plaques. $\mathrm{La}$ Recherche, 153, 414-422.

Le Pichon, X. (2000). Quand les sciences de la Terre redémarrent. $L a$ Recherche, 331, 91-93.

LeGrand, H. E. (1988). Drifting Continents and Shifting Theories (pp. 313). Cambridge: Cambridge University Press.

Lemoine, M. (2000). Faits, modèles et résistance à des idées nouvelles dans les sciences de la Terre, 1900-1970. Genève: Comptes Rendus séminaire Archives Jean Piaget.

Lemoine, M. (2004). De Wegener à la tectonique des plaques: sept fois sept ans de réflexion. Travaux du Comité français d'histoire de la Géologie. 3è série, 18, 103-131.

Lugeon, M. (1902). Les grandes nappes de recouvrement des Alpes du Chablais et de la Suisse. Bulletin de la Société géologique de France, 1(4), 723-825.

Lugeon, M. (1940). Emile Argand. Bulletin de la Société neuchâteloise des Sciences naturelles, 65, 25-53.

Lugeon, M., \& Argand, E. (1905). Sur les grandes nappes de recouvrement de la zone du Piémont. Compte Rendus Académie des Sciences (Paris), 15 mai 1905.

Marvin, U. B. (1985). The British reception of Alfred Wegener's continental drift hypothesis. Earth Sciences History, 4, 138-159.

Masson, H. (1976). Un siècle de géologie des Préalpes: de la découverte des nappes à la recherche de leur dynamique. Eclogae Geologicae Helvetiae, 69, 527-575.

Menard, H. W. (1986). The Ocean of Truth (pp. 351). Princeton: Princeton University Press.

Murray, J., \& Hjort, J. (1912). The Depths of the Ocean (pp. 821). London: Macmillan.

Oreskes, N. (1988). The rejection of continental drift. Historical studies in Physical Sciences, 18, 311-348.

Oreskes, N. (1999). The Rejection of Continental Drift (pp. 420). London: Oxford University Press.

Oreskes, N. (Ed.). (2003). Plate Tectonics. An Insider's History of the Modern Theory of the Earth (pp. 424). Boulder: Westview Press.

Pratt, J. H. (1855). On the attraction of the Himalaya mountains, and of the elevated regions beyond them, upon the plumb-line in India. Philosophical Transactions of the Royal Society of London, 145, 53-100.

Ray, N. (2004). La théorie de la dérive des continents d'Alfred Wegener vue par deux géologues alpins contemporains: Emile Argand et Pierre Termier (pp. 84). Diplôme d'Etudes Approfondies d'Epistémologie et Histoire des Sciences et Techniques. Université Paris VII (unpublished Diploma thesis).

Ray, N. (2005). Pierre Termier et la mobilité continentale. Travaux du Comité français d'histoire de la géologie, 3è série, 19, 51-77.

Sartori, M. (1990). L'unité du Barrhorn (Zone pennique, Valais, Suisse). Mémoire de géologie (Lausanne), 6, 1-156.

Schaer, J.-P. (1991). Emile Argand 1879-1940. Life and portrait of an inspired geologist. Eclogae Geologicae Helvetiae, 84, 511-534. 
Schardt, H. (1893). Sur l'origine des Préalpes romandes. Archives des Sciences physiques et. Naturelles de Genève, 30, 570-583.

Schwarzbach, M. (1980). Alfred Wegener und die Drift der Kontinente (pp. 160). Stuttgart: Wissenschaftliche Verlagsgesellschaft.

Sengör, A. M. C. (1982). The classical theories of orogenesis. In A. Miyashiro, et al. (Eds.), Orogeny (pp. 1-48). Chichester: Wiley.

Sengör, A. M. C. (1990). Plate Tectonics and orogenic research after 25 years: A Tethyan perspective. Earth-Science Reviews, 27, $1-201$.

Sengör, A. M. C. (1998). Die Tethys: vor hundert Jahren und heute. Mitteilung der Osterreichischen Geologischen Gesellschaft, 98, 5-176.

Sengör, A. M. C. (2003a). The repeated rediscovery of mélanges and its implications for the possibility and the role of objective evidence in the scientific enterprise. Geological Society of America, Special Paper, 373, 383-445.

Sengör, A. M. C. (2003b). The large-wavelength deformations of the lithosphere. Geological Society of America, Memoir, 196, 1-347.

Sengör, A. M. C., \& Okurogullari, A. H. (1991). The rôle of accretionary wedges in the growth of continents: Asiatic examples from Argand to Plate Tectonics. Eclogae Geologicae Helvetiae, 84, 535-597.

Staub, R. (1924). Bau der Alpen. Beiträge zur Geologische Karte der Schweiz NF, 52, 1-272.

Staub, R. (1928). Der Bewegungsmechanismus der Erde (pp. 270). Berlin: Borntraeger.

Staub, W. (1940). Emile Argand. Geologische Rundschau, 31, 436-437.

Steinmann, G. (1905). Die Geologische Bedeutung der Tiefseebildung und der ophiolitischen Eruptiva. Berichte der Naturforschende Gesellschaft Freiburg in Breisgau, 16, 46-65.

Stewart, J. A. (1990). Drifting Continents and Colliding Paradigms (pp. 285). Bloomington: Indiana University Press.

Suess, E. (1904). Sur la nature des charriages. Comptes Rendus de l'Académie des Sciences (Paris), 139, 714-716.

Suess, E. (1921-1924). La Face de la Terre (Das Antlitz der Erde) traduit par E. de Margerie (pp. 1724). Paris: Armand Colin.

Termier, P. (1903). Les nappes des Alpes orientales et la synthèse des Alpes. Bulletin Société géologique de France, 3(4), 711-765.

Termier, P. (1921). Epilogue to Suess, E. La Face de la Terre (1921-1924), 1709-1715.

Termier, P. (1922). Les grandes énigmes de la géologie. In P. Termier (Ed.), A la Gloire de la Terre (pp. 317-353). Paris: Nouvelle Librairie nationale.

Termier, P. (1926). La déformation de la surface terrestre au cours des âges. In P. Termier (Ed.), La Joie de Connattre (pp. 117-157). Paris: Nouvelle Librairie nationale.

Thalmann, H. E. (1943). Memorial to Emile Argand. Annual Report for Geological Society of America, 1942, 153-155.
Trümpy, R. (1960). Paleotectonic evolution of the Central and Western Alps. Bulletin of the Geological Society of America, 71, 843-906.

Trümpy, R. (1965). Zur geosynclinalen Vorgeschichte der Schweizer Alpen. Umschau, 18, 573-577.

Trümpy, R. (1971). Stratigraphy in mountain belts. Quaterly Journal of the Geological Society of London, 126(1971), 293-318.

Trümpy, R. (1973). L'évolution de l'orogénèse dans les Alpes Centrales: Interprétation des données stratigraphiques et tectoniques. Eclogae Geologicae Helvetiae, 66, 1-10.

Trümpy, R. (1980). Geology of Switzerland, a Guide-Book. Part A. An Outline of the Geology of Switzerland (104 pp.). Basel and New York: Wepf \& Co.

Trümpy, R. (1983). Die Schweizer Geologie von 1932 bis 1982: Eclogae Geologicae Helvetiae, 76, 65-74.

Trümpy, R. (1985). Die Plattententektonik und die Enstehung der Alpen. Neujaharsblatt der Naturforschende Gesellschaft Zürich, $1985,1-47$

Trümpy, R. (2001). Why plate tectonics was not invented in the Alps. Journal of Earth Science (Geologische Rundschau), 90, 477-483.

Trümpy, R. (2003). Trying to understand Alpine sediments-before 1950. Earth-Science Reviews, 61, 19-42.

Trümpy, R., \& Oberhausser, R. (1999). Zu den Beziehungen zwischen österreichischen und schweizerischen Geologen: die Tektonik der Alpen, 1875-1950. Abhandlungen der Geologischen Bundesanstalt, Wien, 56, 13-28.

Vening-Meinesz, F. A. (1927). Provisional results of determinations of gravity, made during the voyage of Her Majesty's Submarine K.XIII from Holland via Panama to Java. Proceedings, Koninklijke Nederlandse Akademie van Wetenscappen Amsterdam, 30 (7).

Wegener A. L. (1912a). Die Entstehung der Kontinente. Petermanns Geographische Mitteilungen, 58(1), 185-195, 253-256, 305-309.

Wegener, A. L. (1912b). Die Entstehung der Kontinente. Geologische Rundschau, 3, 276-292.

Wegener, A. L. (1915). Die Entstehung der Kontinente und Ozeane (94 pp.). Braunschweig: F. Viewig.

Wegener, A. L. (1922). Die Entstehung der Kontinente und Ozeane (3rd ed., 144 pp.). Braunschweig: F. Viewig.

Wegener, A. L. (1924). La Genèse des Continents et des Océans (trans: M. Reichel, $3 r d$ ed., 161 pp.). Paris: Albert Blanchard.

Wegener, A. L. (1929). Die Entstehung der Kontinente und Ozeane (4th ed., 242 pp.). Braunschweig: F. Viewig.

Wegener, A. L. (1936). Die Entstehung der Kontinente und Ozeane (5th, unchanged, ed., 242 pp.). Braunschweig: F. Viewig.

Wilson, J. T. (1982). Early days in university physics. Annual Review of Earth and Planetary Sciences, 10, 1-14. 